\title{
OPEN Response of a continental fault basin to the global OAE1a during the Aptian: Hongmiaozi Basin, Northeast China
}

\author{
Daijun Fan ${ }^{1,3}$, Xuanlong Shan ${ }^{1,3 凶}$, Yousif M. Makeen ${ }^{1}$, Wentong $\mathrm{He}^{1,3}$, Siyuan $\mathrm{Su}^{1,2}$, \\ Yibo Wang ${ }^{1,3}$, Jian $\mathrm{Yi}^{1,3}$, Guoli Hao ${ }^{1,3}$ \& Yuting Zhao ${ }^{4,5}$
}

This paper presents new research on a lacustrine anoxic event (LAE). These data include stable carbon isotope $\left(\delta^{13} C_{\text {org }}\right)$, pyrite sulfur isotope $\left(\delta^{34} S_{p y}\right)$, trace element and biomarker ratios from the Hongmiaozi Basin (North China) and unravel the response of continental lakes under the influence of early Aptian extreme climate conditions. According to the stratigraphic chronology (122-118 Ma) and carbon isotope correlations, terrestrial sediment was influenced by the early Aptian Oceanic Anoxic Event (OAE1a). The results show that the Xiahuapidianzi Group experienced a significant warming process under negative excursions in carbon isotopes due to the influence of increased carbon dioxide partial pressure $\left(\mathrm{pCO}_{2}\right)$. The climate varied from warm and humid to hot and arid (high $\mathrm{Sr} / \mathrm{Cu}$, low $\mathrm{Rb} /$ $\mathrm{Sr}$, calcareous mudstone), the evaporation and salinity increased (high $\mathrm{Sr} / \mathrm{Ba}$ and $\mathrm{B} / \mathrm{Ga}$ ), and land input sources decreased (low Zr, Ti and Th). Moreover, high total organic carbon (TOC) content was source from bacteria, algae ( $\mathrm{n}$-alkanes), and euxinic depositional environments ( $\mathrm{Pr} / \mathrm{Ph}, \mathrm{Cu} / \mathrm{Zn}$ and U V Mo). In the stage of continuous carbon isotopes positive excursion, organic matter accumulated rapidly. A paleolake environment model has provided a better understanding of current global climate issues under global warming caused by increased carbon dioxide concentrations.

The distinctive features of the Cretaceous period are global warming, bio-events, shale deposition in marine environments due to intermittent oceanic anoxic events (OAEs) and associated isotopic anomalies ${ }^{1,2}$. The Aptian oceanic anoxic event la (OAE1a) at approximately $120 \mathrm{Ma}$ is a typical OAE deposition event. OAE1a is characterized by sedimentary organic matter (Livello Selli) and dramatic fluctuations in the carbon isotope records of carbonate and organic carbon $\left(\delta^{13} \mathrm{C}_{\text {carb }} \text { and } \delta^{13} \mathrm{C}_{\text {org }}\right)^{2}$. These carbon isotope $\left(\delta^{13} \mathrm{C}\right)$ fluctuation records have been interpreted as evidence of perturbations of the global carbon cycle ${ }^{2-4}$. All $\delta^{13} \mathrm{C}$ excursions in $\delta^{13} \mathrm{C}_{\text {carb }}$ and $\delta^{13} \mathrm{C}_{\text {org }}$ records of OAE1a around the world are mainly preserved in marine basins ${ }^{5-7}$. Given the global significance of the perturbations and the ocean-atmosphere system, their record is found in marine sedimentary matter and terrestrial environments ${ }^{8}$. The terrestrial environment has remained almost unexplored except for the Xiagou Formation ${ }^{9}$ in NW China and Yixian Formation ${ }^{10}$ in NE China. Moreover, the associated research only employed field outcrop section samples and stable carbon isotope method. Drilling core samples with better integrity and continuity are more accurate for analysis of stable isotopes. Therefore, such work cannot fully reflect the detailed changes of the terrestrial sedimentary environment during the anoxic period, which further restricts the use of such data in determining the precise causes and changes mechanisms of the paleo-sedimentary environment under greenhouse.

The Xiahuapidianzi group (122-118 Ma) of the Hongmiaozi Basin in the northeastern part of China (Fig. 1) is a typical lacustrine sedimentary stratum. Lake sedimentation is the best carrier to reveal paleoenvironment and paleoclimatic changes because it is very sensitive to climate change ${ }^{11}$. Thus, research on such sedimentation

${ }^{1}$ College of Earth Sciences, Jilin University, Changchun 130012, China. ${ }^{2}$ Shandong Provincial Key Laboratory of Depositional Mineralization and Sedimentary Mineral, Shandong University of Science and Technology, Qingdao 266590, China. ${ }^{3}$ Key Laboratory for Evolution of Past Life and Environment in Northeast Asia (Jilin University), Ministry of Education, Changchun 130012, Jilin, China. ${ }^{4}$ Key Laboratory of Urban Geology and Underground Space Resources, Shandong Provincial Bureau of Geology and Mineral Resources, Qingdao 266000, China. ${ }^{5}$ Qingdao Geo-Engineering Surveying Institute (Qingdao Geological Exploration and Development Bureau), Qingdao 266000, China. ${ }^{\circledR}$ email: shanxl@jlu.edu.cn 


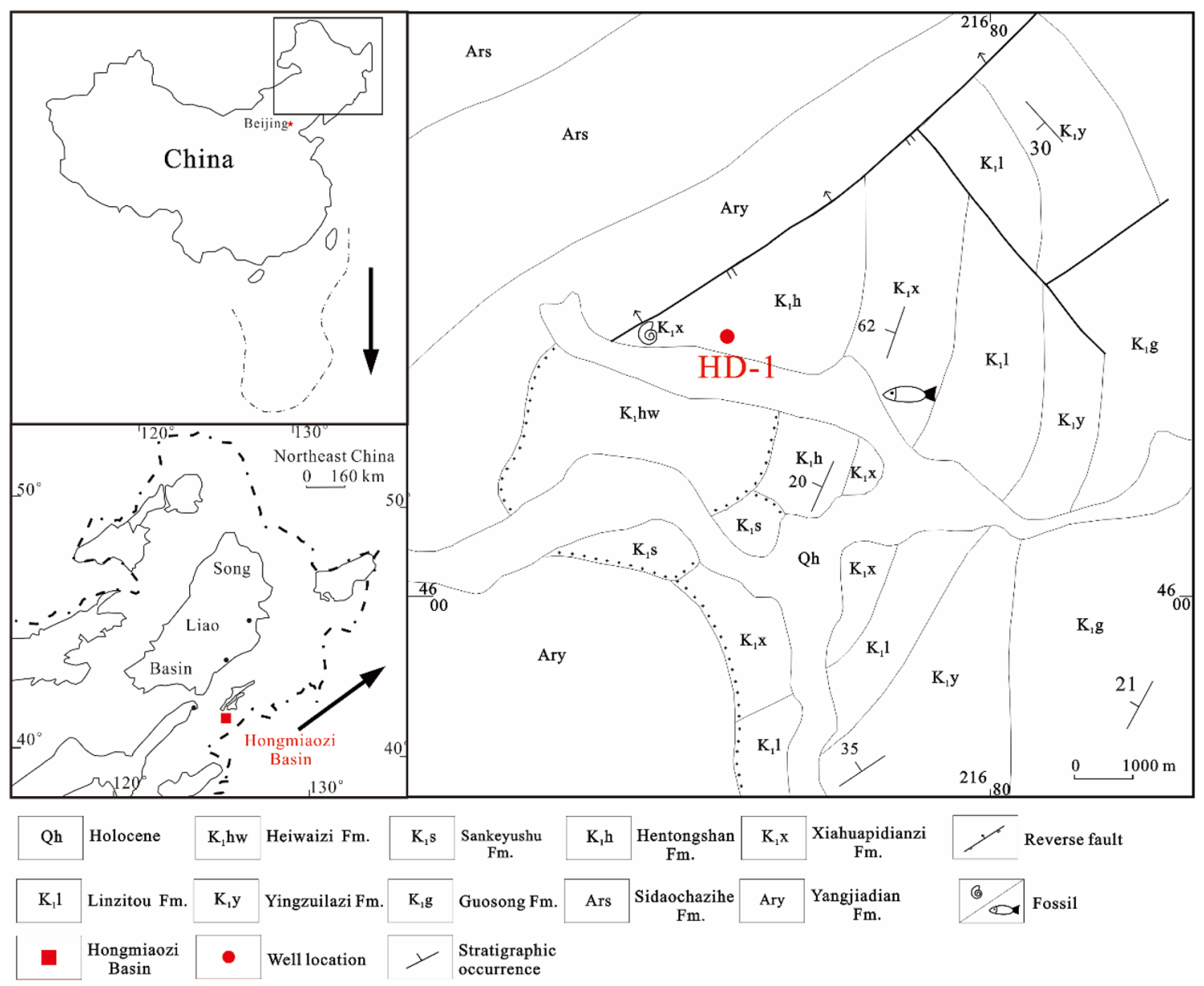

Figure 1. Location of the Hongmiaozi Basin, drilling position and stratum distribution. (This figure was drawn by CorelDRAW Graphics Suite 2019, vision number: 21.3.0.755, url: https://www.corel.com/cn/).

will provide distinct high-resolution records from the Xiahuapidianzi Formation about the paleoenvironment changes within the lacustrine strata.

This study aims to understand the influence of OAE1a on the terrestrial sediment and might also provide a reference for the impact of current lakes on the greenhouse effect through comprehensive indices (e.g., stable isotope geochemistry, element geochemistry, organic geochemistry, etc.). Organic stable carbon isotope and pyrite sulfur isotope methods are widely used for explaining environmental changes (including climate change), bottom-water anoxia and sedimentary environment conditions $s^{1,12,13}$, and trace elements are essential in deciphering the depositional environment ${ }^{14}$.

\section{Geological setting}

The Hongmiaozi Basin is located in the Eastern part of the Yilan-Yitong Fault. It covers an area of $290 \mathrm{~km}^{2}$ and has a $2.4 \mathrm{~km}$ maximum burial depth as determined by the China Geological Survey (CGS). According to the CGS report (in 2015), the basin contains a large number of geophysical and geochemical anomalies for oil and gas. These early achievements act as a foundation for oil and gas exploration and development work.

The geotectonic unit of the Hongmiaozi Basin is a part of the northern margin of the Yingkou-Kuandiantai Arch (III) overlying the JiaoliaoTailong (II) and the Sino Korean paraplatform (I). The tectonic evolution of the Hongmiaozi Basin was mainly influenced by the late Paleozoic Hercynian and Mesozoic Yanshanian movements resulting from the late Middle Jurassic rifting stage (Houjiatun Formation), Early Cretaceous rock melt-filling stage (Changliucun Formation and Guosong Formation), peak volcanic activity stages in the late Early Cretaceous (Yingzuilazi Formation, Xiahuapidianzi Formation and Hengtongshan Formation) and Late Cretaceous rock melt-filling stage (Sankeyushu Formation) $)^{15}$.

The target layer (of the studied formation) within the Hongmiaozi Basin is the Lower Cretaceous Xiahuapidianzi Formation. During deposition of this formation, the basin experienced extensional tectonics and a high peak volcanic activity, thus forming a series of fault depressions spreading from the NE and $\mathrm{NNE}^{16}$. This tectonic evolution was mainly controlled by the subduction of the Mesozoic and Cenozoic paleo-Pacific plates under the Eurasian plate ${ }^{17}$. In the early stage of the depositional period of the Xiahuapidianzi Formation, the Moho surface was uplifted in the central part of the basin, with significant mantle effect. The studied core samples from Hongdi 1 well reveals that the Xiahuapidianzi Formation contains a set of clastic deposits of lakeshore facies and 
semi-deep lake facies dominated by dark mudstone and silty mudstone (Fig. 1). In this study, mudstone samples of the Cretaceous Xiahuapidianzi Formation were used to systematically explain the mechanism underlying the effect of anoxic events on the burial lacustrine organic matter in Hongmiaozi Basin by means of GC-MS, trace element analyses, stable carbon analyses and pyrite sulfur isotope geochemistry. This study is important for understanding the influence of OAE1a on the formation of lacustrine black mudstone.

\section{Materials and methods}

The main lithology of the Xiahuapidianzi Formation in the Hongmiaozi Basin consists of mudstone, muddy siltstone, silty mudstone, and sandstone. The location of the Hongdi 1 well is shown in Fig. 1 . A total of 35 mudstone core samples were collected to determine the stable carbon $\left(\delta^{13} \mathrm{C}_{\mathrm{org}}\right)$, sulfur $\left(\delta^{34} \mathrm{~S}_{\mathrm{py}}\right)$ isotope geochemistry and total organic carbon (TOC) within the studied mudstone. In addition, 7 samples were selected for GC-MS analyses while 24 samples were selected for rare element analyses.

Prior to this analysis, the selected samples were powdered to 200 mesh for Soxhlet extraction analysis to determine the bitumen and hydrocarbon content. The extracted bitumen was separated into asphaltene and maltene fractions. The maltene component separation was carried out using silica gel/alumina column chromatography. Elution with $n$-hexane, dichloromethane/n-hexane (3:1 by volume) and dichloromethane/methanol (2:1 by volume) was performed to separate saturated hydrocarbons, aromatics and nonhydrocarbon components. Then, the saturated and aromatic hydrocarbons were analyzed by GC-MS on an Agilent 6890GC-5975iMS at the China University of Petroleum (Beijing). Certain specific biomarker peaks, such as $\mathrm{n}$-alkanes, tricyclic terpenoids, hopanes and steroids, were identified based on their retention time and the identification results of previous researchers ${ }^{18}$. The distributions of $\mathrm{n}$-alkanes and isoprene were determined using chromatogram ion $\mathrm{m} / \mathrm{z} 85$.

Thirty-two samples were selected for stable carbon isotopic compositions and total organic carbon content (TOC). Firstly, thirty-two samples were crushed to 200 mesh, then weighed respectively. Secondly, the powder samples were acidified with $3 \mathrm{M} \mathrm{HCl}$ to completely remove the inorganic carbon $\left(\mathrm{CaCO}_{3}\right)$. Thirdly, washing the samples many times with deionized water to remove the residual $\mathrm{HCl}$ traces. Finally, the decarbonated samples were dried in an oven at $80{ }^{\circ} \mathrm{C}$ for $10 \mathrm{~h}$ and reweighed to calculate the percentage of carbonate (TIC) in the bulk samples. About 5-10 mg dried samples were wrapped with folded tin cups, then combustion to $\mathrm{CO}_{2}$ with a Eurovector elemental analyzer (EA) in combination with an Element Isoprime isotope ratio mass spectrometer to determine the TOC abundance and carbon isotopic composition. The carbon isotopic values are expressed on a per mil (\%o) basis relative to the Vienna Pee Dee Belemnite standard (V-PDB, $\delta^{13} \mathrm{CV}-\mathrm{PDB}=0$ ) within $0.05 \%$ duplicate measurement precision.

The determination method for the sulfur abundance $\left(\mathrm{TS}_{\mathrm{pyr}}\right)$ and pyrite sulfur isotope $\left(\delta^{34} \mathrm{~S}_{\mathrm{py}}\right)$ composition via Eurovector elemental analyzer in-line with Eurovector Isoprime isotope ratio mass spectrometer (IRMS). The sample of $10 \mathrm{mg}$ was wrapped in a tin cup, and then blown into a quartz tube containing high purity reduced copper by a pure oxygen pulse, heated to $1130^{\circ} \mathrm{C}$. The quartz tube was connected to a $\mathrm{Mg}\left(\mathrm{ClO}_{4}\right)_{2}$ desiccant column (remove water), and connected a 3-m stainless steel GC column packed with Porapak-Q heated to $60{ }^{\circ} \mathrm{C}$ (separate $\mathrm{SO}_{2}$ from other gases). Timed pulses of $\mathrm{SO}_{2}$ reference gas (Airgas $99.999 \%$ purity, $\sim 6 \mathrm{nA}$ ) were introduced at the beginning of the run using an injector connected to the IRMS with a fixed open ratio split. The isotope ratio of the reference gas and samples to the determined by ion beam intensities relative to background values. Each five test samples were corrected by two NBS127 and two NZ1 standard samples, and uncertainties for each analytical session based on these standard analyses were better than $1.0 \%$ and $0.3 \%$, respectively, for abundance and isotope compositions. Isotopic results are expressed in the delta notation as per mil (\%o) deviations from the Canyon Diablo (V-CDT) standard. This method reference to Cao H et al., 2016 ${ }^{19}$. The Stable carbon, pyrite sulfur isotopic and TOC were conducted at the Stable Isotope Laboratory of Oil Shale Test Center of Jilin University.

Trace element were measured at the Oil Shale Test Center of Jilin University by Thermo Scientific ELEMENT high-resolution inductively coupled plasma mass spectrometer (ICP-MS) according to GB/T 14506.30-2010. About $25 \mathrm{mg}$ powder samples were reacted with $1 \mathrm{ml} \mathrm{HF}$ and $0.5 \mathrm{ml} \mathrm{HNO}_{3}$ in a sealing beaker and dissolution at $185^{\circ} \mathrm{C}$ for $24 \mathrm{~h}$. Then, the residues were dissolved with $5 \mathrm{ml} \mathrm{HNO}_{3}$ at $130^{\circ} \mathrm{C}$ for $3 \mathrm{~h}$. Finally, the remainders were diluted with distilled water to $25 \mathrm{ml}$ for trace element measurement. The result show less than $5 \%$ measurement error base on duplicate analysis and standards.

\section{Result}

Lithology and lithofacies division. According to the core identification of HD-1 well, the Xiahuapidianzi Formation (Fig. 2) developed black and gray black mudstone, gray silty mudstone, gray silty mudstone, gray siltstone, deep gray argillaceous fine sandstone, light gray and gray fine sandstone, gray and light gray gravel fine sandstone, light gray medium sandstone, light gray gravel medium sandstone, light gray gravel coarse sandstone. According to the lithology combination and variation characteristics, the Xiahuapidianzi Formation was mainly divided into fan-delta front subfacies, shore-shallow lake subfacies and semi-deep lake subfacies.

Stable carbon isotope and pyrite sulfur isotope. The isotopic analysis results of samples from the Xiahuapidianzi Formation are shown in Fig. 3 and Table 1 . The organic carbon isotopic $\left(\delta^{13} \mathrm{C}_{\text {org }}\right)$ values in the study samples are ranging from $-27.2 \%$ to $-22.7 \%$, with an average of $-24.9 \%, \mathrm{n}=35$. The pyrite sulfur isotope $\left(\delta^{34} \mathrm{~S}_{\mathrm{py}}\right)$ values are between $3.7 \%$ and $17.0 \%$, with an average of $10 \%, \mathrm{n}=33$. The TOC values are range from $0.41 \%$ to $2.35 \%$, with an average of $1.12 \%, \mathrm{n}=34$. The percentages of $\mathrm{TS}_{\mathrm{pyr}}$ values are between $0.16 \%$ and $2.30 \%$, with an average of $0.69 \%, n=33$. In Fig. 3, the sampling depth of the $\delta^{13} \mathrm{C}_{\mathrm{org}}, \delta^{34} \mathrm{~S}_{\mathrm{py}}$, TOC and $\mathrm{TS}_{\mathrm{pyr}}$ range from $767.38 \mathrm{~m}$ to $724.28 \mathrm{~m}$. The negative values of the $\delta^{13} \mathrm{C}_{\text {org }}$ range from $-24.8 \%$ o to $-27.2 \%$, showing a $2.4 \%$ decrease, whereas the values of $\delta^{34} \mathrm{~S}_{\mathrm{py}}$ range from $6.1 \%$ to $14.6 \%$, indicating an $8.5 \%$ increase. The TOC values increase from $0.71 \%$ to $1.87 \%$, displaying an increase of about $1.16 \%$. Similarly, the $\mathrm{TS}_{\text {pyr }}$ values increase from $0.20 \%$ 


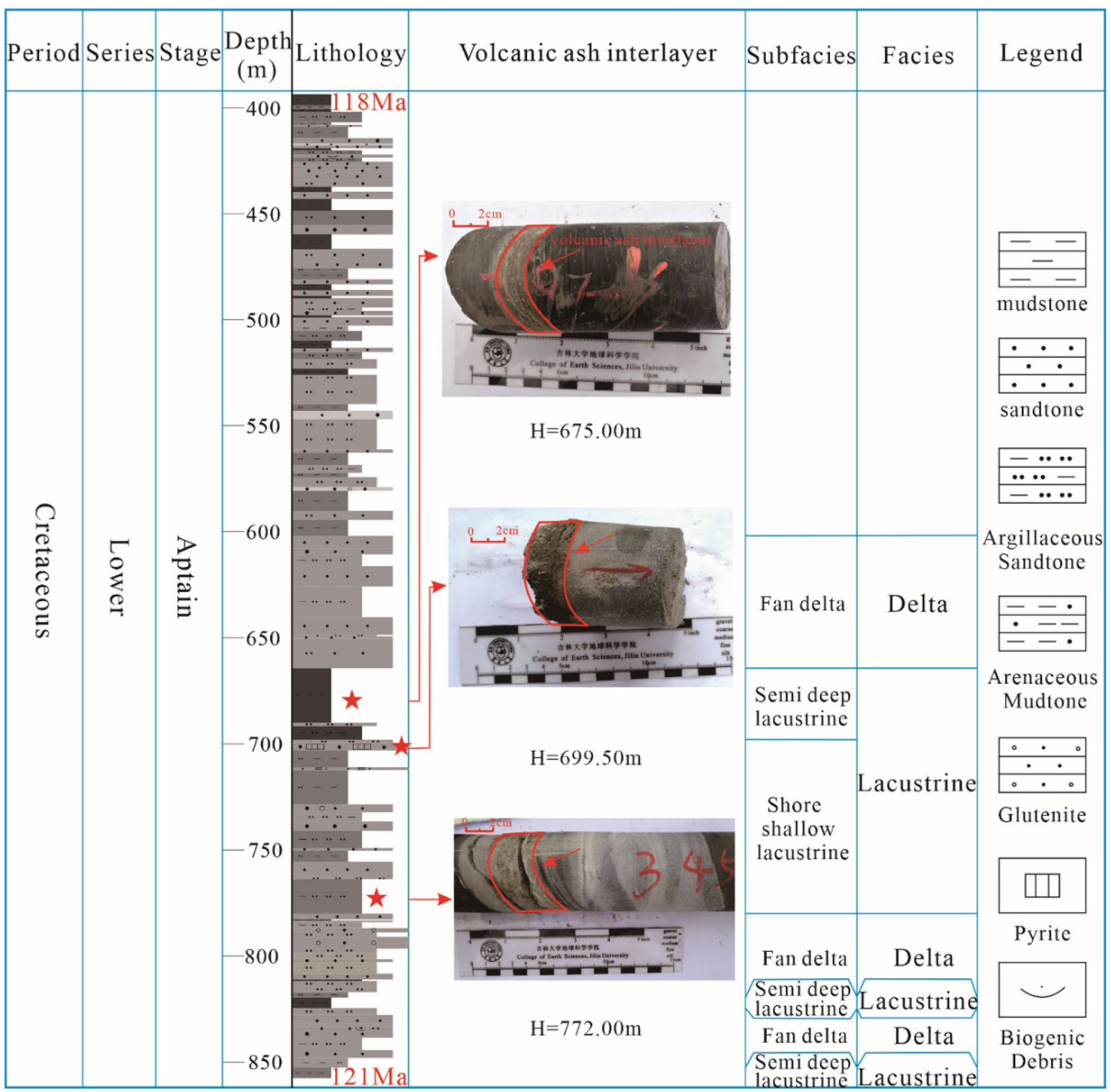

Figure 2. Lithology comprehensive histogram and sedimentary facies division of the Xiahuapidianzi groups. Volcanic ash interlayers in the Xiahuapidianzi Formation sedimentary period (These images were taken by Daijun Fan. This figure was drawn by CorelDRAW Graphics Suite 2019, vision number: 21.3.0.755, url: https:// www.corel.com/cn/).

to $0.96 \%$, revealing an increase of $0.76 \%$. These values indicate a great change in the sedimentary depositional environment within the Xiahuapidianzi Formation. We could easily distinguish the different stages according to change of the stable carbon isotope, pyrite sulfur isotope, TOC and sedimentary facies (Fig. 3).

The interrelationship of stable carbon isotopes $\left(\delta^{13} \mathrm{C}_{\text {org }}\right)$, pyrite sulfur isotopes $\left(\delta^{34} \mathrm{~S}_{\mathrm{py}}\right)$, and TOC can be well correlated by the microbial sulfate reduction (MSR) reaction process as reported by Gill et al. and Berner ${ }^{13,20}$. The MSR can affect most of the organic matter burial and mineralization ${ }^{21}$ :

$$
\begin{gathered}
2 \mathrm{CH}_{2} \mathrm{O}+\mathrm{SO}^{2-} \rightarrow \mathrm{HS}^{-}+2 \mathrm{HCO}^{3-}+\mathrm{H}^{+} \\
\mathrm{Fe}^{2+}+\mathrm{HS}^{-} \rightarrow \mathrm{FeS}_{2}
\end{gathered}
$$

The reaction equations show that sulfate, organic matter, dissolved iron and depositional environment are the decisive factors in the process. 


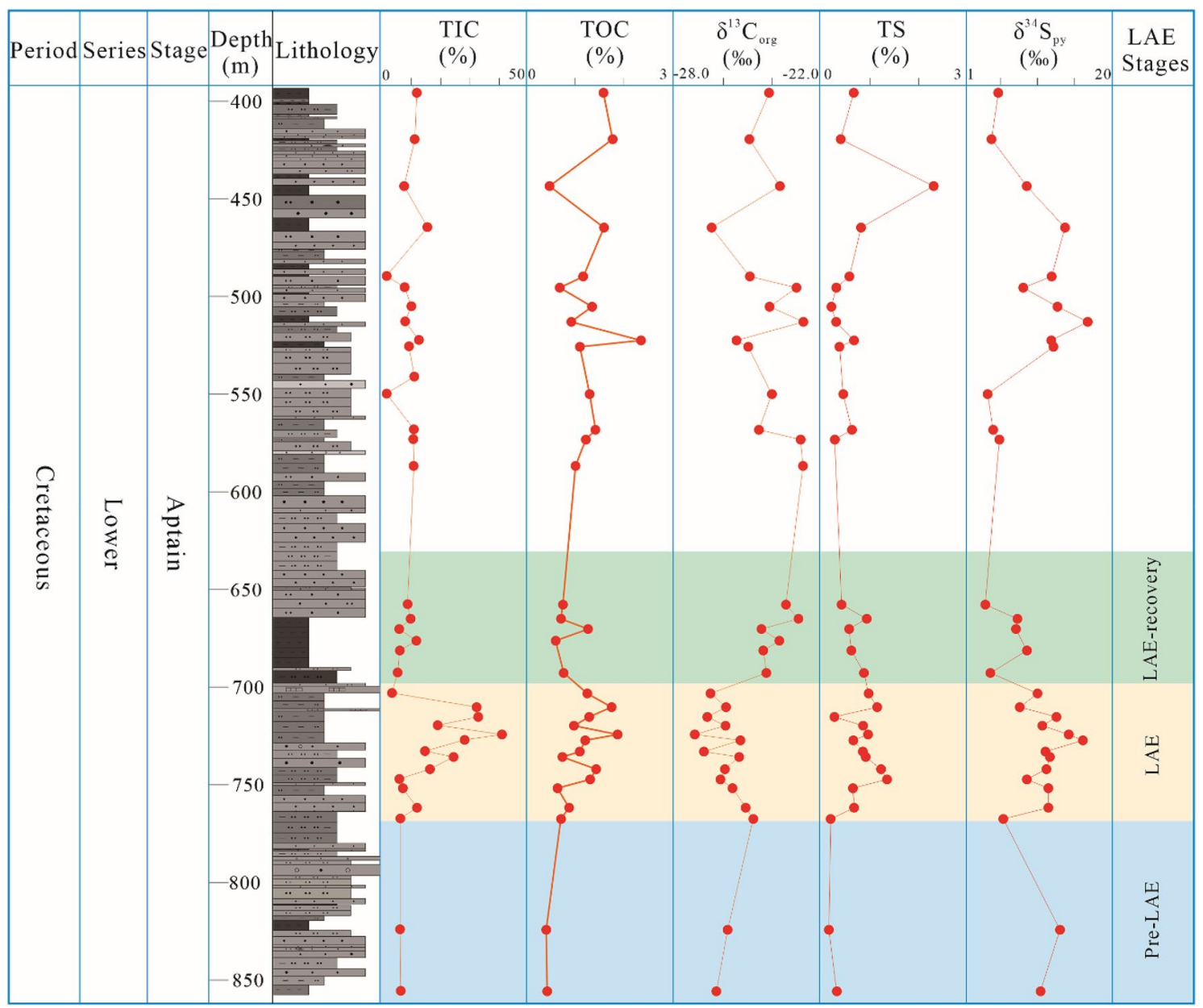

Figure 3. Composite stratigraphic column and vertical variations total inorganic carbon (TIC), total organic carbon (TOC), stable carbon isotope $\left(\delta^{13} \mathrm{C}_{\text {org }}\right)$, total sulfur (TS), and pyrite sulfur isotopes $\left(\delta^{34} \mathrm{~S}_{\mathrm{py}}\right)$ of the Xiahuapidianzi Formation mudstones. The stages division of lacustrine anoxia events (LAE) according to obvious stage variation of isotope, lithology and lithofacies distribution and changes, and changes in trace elements. (This figure was drawn by CorelDRAW Graphics Suite 2019, vision number: 21.3.0.755, url: https:// www.corel.com/cn/).

GC-MS analysis results. Representative GC-MS signals of the aliphatic fraction with m/z 85 and $\mathrm{m} / \mathrm{z} 191$ and $\mathrm{m} / \mathrm{z} 217$ ion chromatograms are shown in Fig. 4. The biomarker distribution could well reflect the source input and depositional environment condition of sediments ${ }^{18}$.

The $n$-alkanes distribution of the Xiahuapidianzi Formation is illustrated in Fig. 5. The higher molecular weight compounds range from $\mathrm{C} 17$ to $\mathrm{C} 23$. Tissot and Welte reported that low to medium molecular weight compounds usually received a substantial input of long chain alkanes, either from algae of plant curricular waxes ${ }^{22}$.

The concentration of pristine $(\mathrm{Pr})$ and phytane $(\mathrm{Ph})$ in acyclic isoprenoids are the most important terms ${ }^{23}$. The ratio of pristane to phytane $(\mathrm{Pr} / \mathrm{Ph})$ is an indicator of the redox conditions for paleoenvironment conditions ${ }^{18}$. It is generally believed that higher $\mathrm{Pr} / \mathrm{Ph}$ ratios $(>1)$ reveal oxidation conditions and low $\mathrm{Pr} / \mathrm{Ph}$ ratios $(<1)$ indicate a reduction environment ${ }^{24}$. The $\mathrm{Pr} / \mathrm{Ph}$ ratio of the Xiahuapidianzi Formation are in the range of 0.25 to 1.01 , with an average of 0.63 . The $\mathrm{Pr} / \mathrm{C} 17$ and $\mathrm{Ph} / \mathrm{C} 18$ ratios are used to indicate the degree of activity of microorganisms. Generally, the smaller the ratio are, the stronger the activity of microorganisms. The ratio of $\mathrm{Pr} / \mathrm{C} 17 \mathrm{and} \mathrm{Ph} / \mathrm{C} 18$ are $0.04-0.93$ and $0.06-1.19$, respectively.

The $\mathrm{m} / \mathrm{z} 191$ mass fragmentogram of the saturated hydrocarbon fractions of all the analyzed samples displayed high proportions of hopanes relative to tricyclic terpane as shown in Fig. 5. The relatively high tricyclic terpane concentrations in the sediment (Fig. $5 \mathrm{~m} / \mathrm{z}=191$ ) are consistent with the derivation from lacustrine algal organic matter ${ }^{25}$.

Gammacerane was originally reported as an environmental salinity index for both marine and lacustrine environemts ${ }^{18}$, and the Gammacerane Index (gammacerane/C30 hopane) is believed to reflect the extent of the salinity stratified water column during deposition ${ }^{26}$. The gammacerane $/ \mathrm{C}_{30}$ hopane ratios range from 0.16 to 0.27 , with an average value of 0.22 , in the Xiahuapidianzi Formation samples (Table 2).

The distributions of diasteranes and steranes $\left(\mathrm{C}_{27}, \mathrm{C}_{28}\right.$ and $\left.\mathrm{C}_{29}\right)$ are shown in the $\mathrm{m} / \mathrm{z} 217$ ion chromatograms (Fig. 5). The relative abundances of $\mathrm{C}_{27}, \mathrm{C}_{28}$ and $\mathrm{C}_{29}$ regular steranes are calculated and the results are given in 


\begin{tabular}{|c|c|c|c|c|c|c|}
\hline Num & $\operatorname{Depth}(\mathrm{m})$ & $\delta^{13} C_{\text {org }}(\% o)$ & TOC (\%) & $\delta^{34} S_{\text {pyr }}(\% o)$ & TS (\%) & TIC (\%) \\
\hline 1 & 395.80 & -24.1 & 1.58 & 5.4 & 0.67 & 11.9 \\
\hline 2 & 419.60 & -24.9 & 1.77 & 4.5 & 0.4 & 11.1 \\
\hline 3 & 443.55 & -23.7 & 0.48 & 9.1 & 2.3 & 7.5 \\
\hline 4 & 464.65 & -26.5 & 1.59 & 14.1 & 0.82 & 15.4 \\
\hline 5 & 489.65 & -24.9 & 1.17 & 12.3 & 0.58 & 1.6 \\
\hline 6 & 495.40 & -23.0 & 0.69 & 8.7 & 0.31 & 7.7 \\
\hline 7 & 505.15 & -24.1 & 1.35 & 13.1 & 0.21 & 10.0 \\
\hline 8 & 513.00 & -22.7 & 0.92 & 17.0 & 0.31 & 7.9 \\
\hline 9 & 522.50 & -25.5 & 2.35 & 12.3 & 0.67 & 12.6 \\
\hline 10 & 525.65 & -25.0 & 1.1 & 12.6 & 0.38 & 9.2 \\
\hline 11 & 549.90 & -24.0 & 1.3 & 4.0 & 0.45 & 11.0 \\
\hline 12 & 568.15 & -24.5 & 1.42 & 4.8 & 0.63 & 10.8 \\
\hline 13 & 573.20 & -22.8 & 1.22 & 5.6 & 0.28 & 10.6 \\
\hline 14 & 586.81 & -22.7 & 1.01 & - & - & 10.8 \\
\hline 15 & 657.65 & -23.4 & 0.75 & 3.7 & 0.42 & 8.7 \\
\hline 16 & 665.10 & -22.9 & 0.71 & 7.9 & 0.93 & 9.7 \\
\hline 17 & 670.30 & -24.4 & 1.27 & 7.7 & 0.57 & 5.8 \\
\hline 18 & 676.35 & -23.7 & - & - & - & 11.7 \\
\hline 19 & 681.35 & -24.4 & 0.6 & 9.1 & 0.62 & 6.1 \\
\hline 20 & 692.72 & -24.2 & 0.77 & 4.4 & 0.88 & 5.3 \\
\hline 21 & 703.25 & -26.5 & 1.25 & 10.5 & 0.97 & 3.4 \\
\hline 22 & 710.35 & -25.9 & 1.75 & 8.2 & 1.15 & 32.2 \\
\hline 23 & 715.28 & -26.7 & 1.29 & 13.0 & 0.27 & 32.8 \\
\hline 24 & 719.73 & -25.9 & 0.98 & 11.1 & 0.86 & 19.0 \\
\hline 25 & 724.28 & -27.2 & 1.87 & 14.6 & 0.96 & 40.9 \\
\hline 26 & 727.15 & -25.3 & 1.21 & 16.4 & 0.66 & 28.2 \\
\hline 27 & 732.95 & -26.8 & 1.1 & 11.5 & 0.86 & 14.6 \\
\hline 28 & 735.81 & -25.4 & 0.74 & 12.1 & 0.91 & 24.4 \\
\hline 29 & 742.08 & -25.9 & 1.43 & 11.7 & 1.23 & 16.3 \\
\hline 30 & 747.15 & -26.1 & 1.31 & 9.1 & 1.35 & 5.9 \\
\hline 31 & 751.83 & -25.6 & 0.64 & 11.9 & 0.65 & 7.1 \\
\hline 32 & 761.80 & -25.1 & 0.88 & 11.9 & 0.68 & 11.9 \\
\hline 33 & 767.38 & -24.8 & 0.71 & 6.1 & 0.2 & 6.2 \\
\hline 34 & 824.25 & -25.8 & 0.41 & 13.4 & 0.16 & 6.1 \\
\hline 35 & 855.65 & -26.3 & \begin{tabular}{|l|}
0.43 \\
\end{tabular} & 10.9 & 0.32 & 6.4 \\
\hline
\end{tabular}

Table 1. Stable carbon isotope $\left(\delta^{13} \mathrm{C}_{\text {org }}\right)$, total organic carbon (TOC), total inorganic carbonate (TIC), pyrite sulfur isotopes $\left(\delta^{34} \mathrm{~S}_{\mathrm{py}}\right)$, and total sulfur (TS) data of the Xiahuapidianzi Formation samples from Hongmiaozi Basin.

Table 2. Waples and Machihara documented that the relative distribution of $\mathrm{C}_{27}, \mathrm{C}_{28}$, and $\mathrm{C}_{29}$ regular steranes can be used to indicate the source of organic matter input ${ }^{27}$. From Fig. $5, \mathrm{C}_{27}$ sterane presents a dominant abundance in the analyzed samples of the Xiahuapidianzi Formation. The analyzed samples (Table 2) show a high proportion of $\mathrm{C}_{27}(37.11-43.74 \%)$ and $\mathrm{C}_{28}(25.20-28.57 \%)$ compared to $\mathrm{C}_{29}(28.32-35.58 \%)$ steranes. The samples also have relatively high $\mathrm{C} 27 / \mathrm{C} 29$ regular sterane ratios in the range of 1.08-1.54 (Table 2). Figure 4A shows that the Xiahuapidianzi Group was sedimentary in a suboxic-anoxic environment and algae were the main source of organic matter. Figure $4 \mathrm{~B}$ shows the triangular plot of the three end members of the regular steranes and suggests the predominance of planktonic, algal and bacterial organic matter source input to the sediment of the Xiahuapidianzi Formation.

Trace elements. Trace element data of the Xiahuapidianzi Formation samples and relevant ratios (e.g., V/ $(\mathrm{V}+\mathrm{Ni}), \mathrm{Cu} / \mathrm{Zn}$, and $\mathrm{Sr} / \mathrm{Ba}$ ) are list in Table 3. These elements (e.g., $\mathrm{V}, \mathrm{Sr}, \mathrm{Ba}, \mathrm{B}, \mathrm{Rb}$, and $\mathrm{Ni}$ ) and their ratios are always useful in various studies to decipher the paleoclimate, paleosalinity, and redox conditions during the deposition of sedimentary rocks in basins ${ }^{14,29-33}$. Terrigenous debris are common components in sediments or sedimentary rocks. The impact of terrigenous detrital must be evaluated before the sedimentary environment is judged. The best way to check whether the content of a given element is dominantly controlled by the detrital flux is to crossplot the trace element versus aluminum or titanium, which are commonly overwhelmingly of detrital origin. Here we choose Ti (titanium) for evaluation whether the influence by the detrital flux. Because 

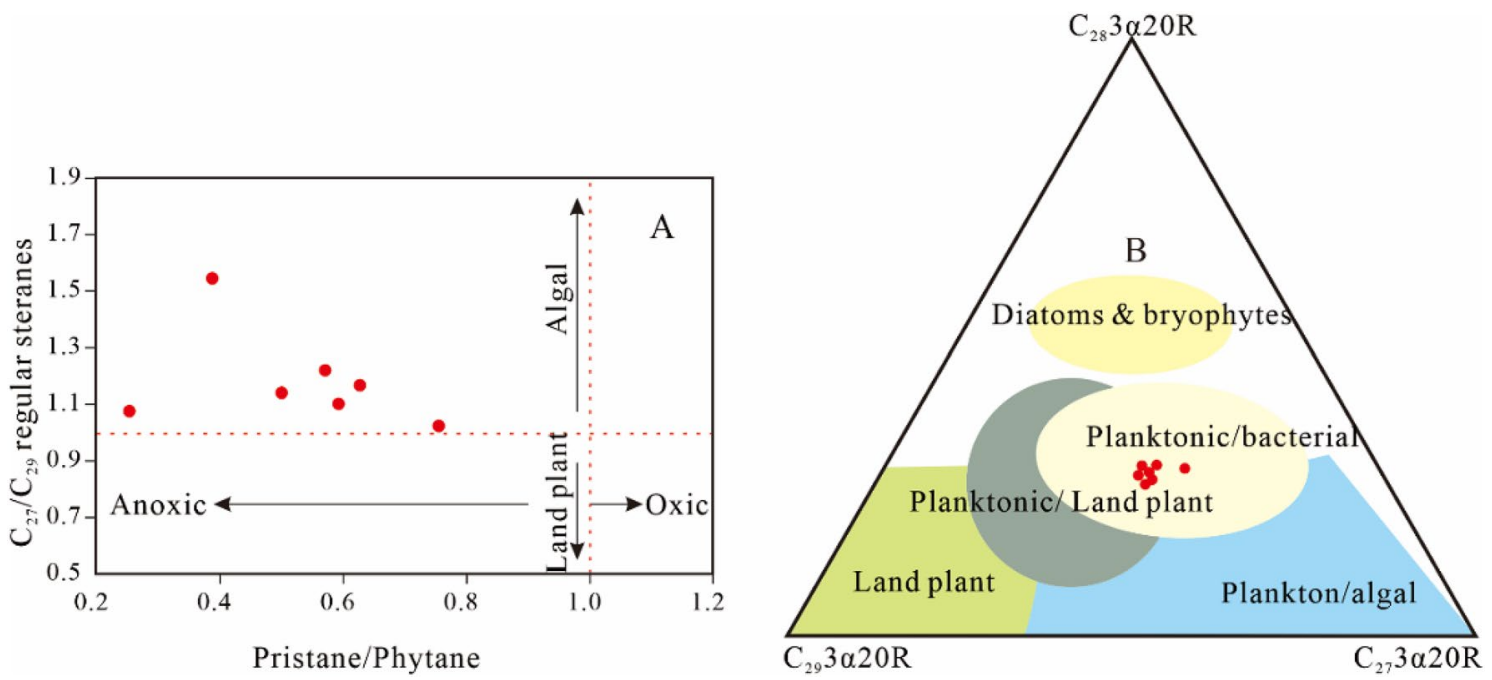

Figure 4. A: Pristane/Phytane versus $C 27 / C 29$ regular steranes plot. $B: C_{27}, C_{28}, C_{29} \alpha a \alpha-20 R$ regular sterane triangular diagram indicating the compositions, organic matter input, and depositional environment for the analyzed Xiahuapidianzi Formation extracts (modified after Makeen, Y. F. et al. ${ }^{28}$ ).

$\mathrm{Ti}$ is commonly overwhelmingly of detrital origin and which are usually immobile during diagenesis ${ }^{34}$. From the crossplot results (Fig. 6), V, Ni, Ba with little $\mathrm{R}^{2}$, reflect almost unaffected by terrigenous detrital flux.

Paleoclimate. Climate is a major factor controlling sedimentary organic matter (OM) input ${ }^{35}$. The climatic conditions can influence the geochemical characteristics of sediments in lacustrine environments by controlling the terrigenous material flux and diagenetic processes ${ }^{32}$. Trace elements $\mathrm{Sr}, \mathrm{Cu}$, and $\mathrm{Rb}$ are considered to be sensitive to paleoclimate, and $\mathrm{Sr} / \mathrm{Cu}$ and $\mathrm{Rb} / \mathrm{Sr}$ ratios may provide useful clues to infer paleoclimatic changes ${ }^{31}$. In dry and hot climates, the lake water area shrinks. In response, Sr becomes enriched in the lake water, while $\mathrm{Cu}$ precipitates out. Thus, the $\mathrm{Sr} / \mathrm{Cu}$ ratio is used to reflect the climate conditions during deposition ${ }^{36}$. Previous studies evaluating palaeoclimate observed consistent results on the ratio of $\mathrm{Sr} / \mathrm{Cu}$. When the ratio of $\mathrm{Sr} / \mathrm{Cu}$ in the range of 1 to 10 , it indicates the climate is humid to semi-humid. When the ratio of $\mathrm{Sr} / \mathrm{Cu}$ range from 10 to 20 , it reveals the climate is semi-humid to semi-arid. When the ratio of $\mathrm{Sr} / \mathrm{Cu}$ larger than 20, it manifests the climate is arid and $\mathrm{hot}^{37}$. The $\mathrm{Sr} / \mathrm{Cu}$ ratios of this study vary greatly from 5.39 to 29.96, with an average of 11.14, $\mathrm{n}=24$. The $\mathrm{Rb} / \mathrm{Sr}$ ratios vary from 0.09 to 1.36 , with an average of $0.68, \mathrm{n}=24$. The ratios of $\mathrm{Sr} / \mathrm{Cu}$ and $\mathrm{Rb} / \mathrm{Sr}$ are generally $<10$ and $>0.6$, respectively (Table 3 ), although an obvious change occurs from 710.20 to $741.93 \mathrm{~m}$ and 595.65-464.50 m, with $\mathrm{Sr} / \mathrm{Cu}(>10)$ and $\mathrm{Rb} / \mathrm{Sr}(<0.60)$ (Fig. 7).

Paleosalinity. Trace elements $\mathrm{Sr}, \mathrm{Ba}, \mathrm{Ga}$, and B are also sensitive to salinity. Sr/Ba and B/Ga ratio can be useful indicators for assessing paleosalinity ${ }^{29,30,33}$. Sr/Ba values $<0.6$ indicates a freshwater setting, between 1.0 and 0.6 represent brackish water, and $>1$ indicates saline water in an arid climate ${ }^{38}$. The $\mathrm{Sr} / \mathrm{Ba}$ ratios in all samples vary from 0.20 to 1.72 , with a mean of 0.62 (Table 3). The ratios of $\mathrm{Sr} / \mathrm{Ba}$ are lower than 1.0 except from $710-736 \mathrm{~m}$, which exceeds 1.2. B/Ga values greater than 5.0 indicate salt water, from 3.0 to 5.0 indicate brackish water, and less than 3.0 indicate fresh water ${ }^{39}$. The B/Ga ratios in all samples are 1.99-8.66, with a mean of 4.24 (Table 3). A significant increase of B/Ga values occurs from 710 to $736 \mathrm{~m}$, with values greater than 5.0 (Fig. 7).

Paleoredox conditions. Trace elements such as V, U, Ni, Co, Cr, and Ce are generally considered "redoxsensitive metals" and could be used as paleoredox proxies with minimal detrital influence in lake environments ${ }^{40}$. It has been widely accepted that the trace element ratios of $\mathrm{U} / \mathrm{Th}, \mathrm{Cu} / \mathrm{Zn}$, and $\mathrm{V} /(\mathrm{V}+\mathrm{Ni})$ can be used as an index for paleoredox conditions ${ }^{40}$. Hatch and Leventhal documented that an environment characterized by strongly reducing and euxinic conditions led to $\mathrm{V} /(\mathrm{V}+\mathrm{Ni})$ ratios greater than 0.84 , while that under suboxic-anoxic environments led to $\mathrm{V} /(\mathrm{V}+\mathrm{Ni})$ ratios of $0.60-0.84^{40,41}$. The $\mathrm{V} /(\mathrm{V}+\mathrm{Ni})$ ratios for all the Xiahuapidianzi Formation samples vary between 0.64 and 0.79 , with a mean of 0.74 (Table 3). A ratio of $\mathrm{Cu} / \mathrm{Zn}$ greater than 0.63 indicates an oxidizing environment, a value of $0.50-0.63$ indicates a weakly oxidizing environment, and a value less than 0.21 indicates a reducing environment. The $\mathrm{Cu} / \mathrm{Zn}$ ratios for all the Xiahuapidianzi Formation samples vary between 0.20 and 0.52 , with a mean of 0.32 (Table 3). Furthermore, U, V and Mo have a variety of chemical valence states, which are significantly affected by the redox state during deposition; most of them are authigenic components in sediments or sedimentary rocks, and almost no migration occurs during diagenesis, keeping the original record of deposition. $\mathrm{U}$ and $\mathrm{V}$ are reduced and can accumulate under denitrifying conditions, whereas Mo are enriched mainly under sulfate-reducing conditions alone. Based on the difference in geochemical properties of these two elements, $\mathrm{U}$ and $\mathrm{V}$ enrichment without Mo enrichment, we could infer suboxic/anoxic depositional without free $\mathrm{H}_{2} \mathrm{~S}$. Conversely, sediments exhibiting concurrent enrichments in $\mathrm{U}, \mathrm{V}$ and Mo reflect euxinic conditions ${ }^{34}$.

Terrigenous detrital. Rivers carry large amounts of terrigenous detrital matter into lakes. Thus, an increase in detrital input probably results from increased river input. The concentrations of high field strength elements, such as Ti (titanium) and Th (thorium), can reflect changes in the input of terrigenous detrital matter. Because $\mathrm{Ti}$ (titanium) and Th (thorium) are commonly overwhelmingly of detrital origin and usually immobile during diagenesis ${ }^{42}$. The content of Ti (titanium) and Th (thorium) are $2729-6041 \mu \mathrm{g} / \mathrm{g}$ mean $=4706 \mu \mathrm{g} / \mathrm{g}(\mathrm{n}=24)$ and $5.5-16.7 \mu \mathrm{g} / \mathrm{g}($ mean $=12.6 \mu \mathrm{g} / \mathrm{g}, \mathrm{n}=24)($ Table 3$)$. 


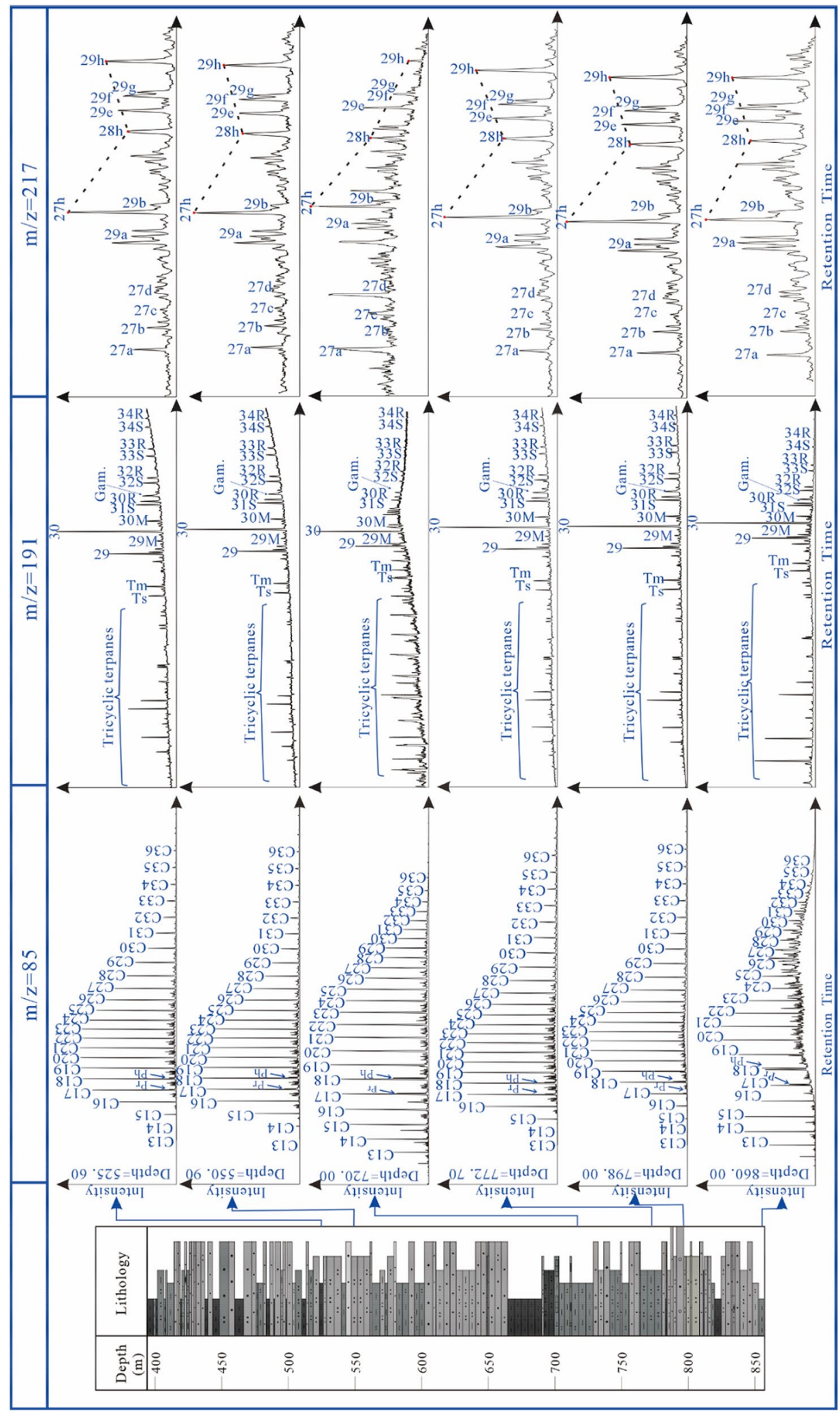

Figure 5. $\mathrm{m} / \mathrm{z}=85, \mathrm{~m} / \mathrm{z}=191$, and $\mathrm{m} / \mathrm{z}=217$ mass fragmentograms of the saturated hydrocarbon fractions of six representative Xiahuapidianzi Formation mudstone samples. 


\begin{tabular}{|l|l|l|l|l|l|l|l|l|}
\hline Depth $(\mathbf{m})$ & $\mathbf{P r} / \mathbf{C}_{17}$ & $\mathbf{P h} / \mathbf{C}_{18}$ & $\mathbf{P r} / \mathbf{P h}$ & $\mathbf{G I} / \mathbf{C}_{30} \mathbf{H}$ & $\mathbf{C}_{27} / \mathbf{C}_{29}$ & $\mathbf{C}_{27}(\%)$ & $\mathbf{C}_{28}(\%)$ & $\mathbf{C}_{29}(\%)$ \\
\hline 525.60 & 0.04 & 0.06 & 0.57 & 0.27 & 1.22 & 39.27 & 28.57 & 32.16 \\
\hline 550.90 & 0.05 & 0.06 & 0.63 & 0.23 & 1.17 & 39.83 & 26.08 & 34.09 \\
\hline 720.00 & 0.39 & 0.36 & 0.39 & 0.22 & 1.54 & 43.74 & 27.94 & 28.32 \\
\hline 773.50 & 0.05 & 0.08 & 0.50 & 0.22 & 1.14 & 38.76 & 27.27 & 33.97 \\
\hline 798.00 & 0.12 & 0.23 & 0.25 & 0.23 & 1.08 & 37.11 & 28.43 & 34.47 \\
\hline 860.00 & 0.93 & 1.19 & 0.59 & 0.16 & 1.10 & 39.22 & 25.20 & 35.58 \\
\hline
\end{tabular}

Table 2. n-Alkane and isoprenoids biomarker ratios calculated from TIC, $\mathrm{m} / \mathrm{z}=191, \mathrm{~m} / \mathrm{z}=217$ mass fragmentogram of selected Xihuapidianzi Formation extracts. $\mathrm{Pr}$ pristine, $\mathrm{Ph}$ phystane, $\mathrm{GI} / \mathrm{C}_{30} \mathrm{H}$ gammacerane index/ $\mathrm{C}_{30}$ hopane, $\mathrm{C}_{27}, \mathrm{C}_{28}, \mathrm{C}_{29} \mathrm{C}_{27}, \mathrm{C}_{28}, \mathrm{C}_{29}$ a a a regularsteranes (20R).

\begin{tabular}{|c|c|c|c|c|c|c|c|c|c|c|c|c|c|c|c|c|c|c|c|}
\hline Depth (m) & B & Ti & V & $\mathrm{Ni}$ & $\mathrm{Cu}$ & Zn & Ga & $\mathbf{R b}$ & Sr & $\mathrm{Zr}$ & Ba & Th & U & Mo & $\mathrm{Cu} / \mathrm{Zn}$ & $\mathrm{Sr} / \mathbf{B a}$ & \begin{tabular}{|l}
$\mathrm{B}$ \\
$/ \mathrm{Ga}$
\end{tabular} & \begin{tabular}{|l|}
$\mathrm{Rb}$ \\
$/ \mathrm{Sr}$
\end{tabular} & \begin{tabular}{|l}
$\mathrm{Sr}$ \\
$/ \mathrm{Cu}$
\end{tabular} \\
\hline 395.65 & 70 & 3404 & 114 & \begin{tabular}{|l|}
36.1 \\
\end{tabular} & 33.5 & 92 & 19.9 & 157 & \begin{tabular}{|l|}
457 \\
\end{tabular} & \begin{tabular}{|l|}
173.2 \\
\end{tabular} & 615 & \begin{tabular}{|l|}
10.7 \\
\end{tabular} & \begin{tabular}{|l|}
3.7 \\
\end{tabular} & 3.23 & \begin{tabular}{|l|}
0.37 \\
\end{tabular} & 0.74 & \begin{tabular}{|l|}
3.51 \\
\end{tabular} & \begin{tabular}{|l|}
0.34 \\
\end{tabular} & 13.64 \\
\hline 464.50 & 72 & 3701 & 125 & \begin{tabular}{|l|}
39.6 \\
\end{tabular} & 37.2 & 95 & $21 . .0$ & 167 & 481 & 180.5 & 675 & \begin{tabular}{|l|}
11.7 \\
\end{tabular} & 3.8 & 3.47 & 0.39 & 0.71 & 3.44 & 0.35 & 12.92 \\
\hline 495.25 & 87 & 5293 & 118 & \begin{tabular}{|l|}
37.8 \\
\end{tabular} & 38.0 & 145 & 31.0 & 292 & 266 & 294.4 & 702 & 16.5 & 2.7 & 1.07 & 0.26 & 0.38 & 2.82 & 1.10 & 7.01 \\
\hline 505.00 & 85 & 5020 & 110 & 40.5 & 37.1 & 135 & 29.0 & 254 & 276 & 303.6 & 659 & \begin{tabular}{|l|}
15.1 \\
\end{tabular} & 2.4 & 1.06 & 0.28 & 0.42 & 2.93 & 0.92 & 7.44 \\
\hline 512.85 & 78 & 5005 & 101 & 49.0 & \begin{tabular}{|l|}
33.7 \\
\end{tabular} & 112 & 26.4 & 221 & 318 & 255.1 & 658 & \begin{tabular}{|l|}
13.4 \\
\end{tabular} & 2.0 & 1.02 & 0.30 & 0.48 & 2.96 & \begin{tabular}{|l|}
0.69 \\
\end{tabular} & \begin{tabular}{|l|}
9.42 \\
\end{tabular} \\
\hline 522.35 & 79 & 4809 & 115 & 52.9 & 42.5 & 149 & 27.6 & 253 & 258 & 236.4 & 1280 & 14.2 & 2.1 & 6.07 & 0.29 & 0.20 & 2.84 & 0.98 & \begin{tabular}{|l|l|}
6.07 \\
\end{tabular} \\
\hline 525.50 & 87 & 5120 & 114 & 51.5 & 37.5 & 118 & 27.2 & 248 & 348 & 245.2 & 691 & 13.7 & 2.0 & 1.46 & 0.32 & 0.50 & 3.20 & \begin{tabular}{|l|}
0.71 \\
\end{tabular} & 9.28 \\
\hline 549.75 & 100 & 5101 & 132 & \begin{tabular}{|l|}
40.7 \\
\end{tabular} & 41.6 & 148 & 28.6 & 236 & 233 & \begin{tabular}{|l|}
245.7 \\
\end{tabular} & 583 & 13.5 & 2.3 & 1.11 & 0.28 & \begin{tabular}{|l|}
0.40 \\
\end{tabular} & \begin{tabular}{|l|}
3.49 \\
\end{tabular} & \begin{tabular}{|l|}
1.02 \\
\end{tabular} & 5.59 \\
\hline 573.05 & 100 & 5870 & 124 & 45.1 & 41.6 & 127 & \begin{tabular}{|l|}
29.9 \\
\end{tabular} & 289 & 291 & \begin{tabular}{|l|}
238.9 \\
\end{tabular} & 657 & 15.4 & 2.1 & 1.00 & 0.33 & 0.44 & 3.35 & \begin{tabular}{|l|}
0.99 \\
\end{tabular} & 7.01 \\
\hline 586.66 & 104 & 5645 & 115 & \begin{tabular}{|l|}
41.0 \\
\end{tabular} & 31.1 & 137 & 28.1 & 250 & 244 & \begin{tabular}{|l|}
219.7 \\
\end{tabular} & 622 & \begin{tabular}{|l|}
12.9 \\
\end{tabular} & 2.2 & \begin{tabular}{|l|}
1.07 \\
\end{tabular} & 0.23 & \begin{tabular}{|l|}
0.39 \\
\end{tabular} & \begin{tabular}{|l|}
3.69 \\
\end{tabular} & \begin{tabular}{|l|}
1.02 \\
\end{tabular} & \begin{tabular}{|l|}
7.86 \\
\end{tabular} \\
\hline 657.50 & 119 & 5807 & 118 & 39.3 & 35.7 & 129 & 30.1 & 222 & \begin{tabular}{|l|}
278 \\
\end{tabular} & 260.6 & 640 & 14.5 & 2.2 & \begin{tabular}{|l|}
0.72 \\
\end{tabular} & \begin{tabular}{|l|}
0.28 \\
\end{tabular} & 0.43 & 3.94 & \begin{tabular}{|l|}
0.80 \\
\end{tabular} & \begin{tabular}{|l|}
7.77 \\
\end{tabular} \\
\hline 664.95 & 143 & 5602 & 125 & \begin{tabular}{|l|}
37.6 \\
\end{tabular} & \begin{tabular}{|l|}
34.4 \\
\end{tabular} & 135 & 29.5 & 212 & 273 & \begin{tabular}{|l|}
243.3 \\
\end{tabular} & 707 & \begin{tabular}{|l|}
13.5 \\
\end{tabular} & 2.0 & 0.95 & 0.26 & \begin{tabular}{|l|}
0.39 \\
\end{tabular} & \begin{tabular}{|l|}
4.84 \\
\end{tabular} & \begin{tabular}{|l|}
0.78 \\
\end{tabular} & \begin{tabular}{|l|}
7.93 \\
\end{tabular} \\
\hline 710.20 & 145 & 3167 & 96 & 27.2 & 33.5 & 85 & 16.9 & 123 & 685 & \begin{tabular}{|l|}
124.8 \\
\end{tabular} & 511 & 6.8 & 2.1 & 2.30 & 0.40 & \begin{tabular}{|l|}
1.34 \\
\end{tabular} & \begin{tabular}{|l|}
8.58 \\
\end{tabular} & \begin{tabular}{|l|}
0.18 \\
\end{tabular} & 20.46 \\
\hline 719.58 & 108 & 4076 & 131 & \begin{tabular}{|l|}
73.0 \\
\end{tabular} & 42.5 & 99 & 22.0 & 1640 & 585 & \begin{tabular}{|l|l|}
173.0 \\
\end{tabular} & 643 & 8.4 & 2.7 & \begin{tabular}{|l|l|}
7.01 \\
\end{tabular} & \begin{tabular}{|l|}
0.43 \\
\end{tabular} & \begin{tabular}{|l|}
0.91 \\
\end{tabular} & \begin{tabular}{|l|}
4.89 \\
\end{tabular} & \begin{tabular}{|l|}
0.28 \\
\end{tabular} & \begin{tabular}{|l|}
13.76 \\
\end{tabular} \\
\hline 724.13 & 79 & 2729 & 90 & 26.2 & 29.9 & 74 & 14.4 & 83 & 894 & \begin{tabular}{|l|l}
114.0 \\
\end{tabular} & 522 & 5.5 & 2.0 & 8.18 & \begin{tabular}{|l|}
0.40 \\
\end{tabular} & \begin{tabular}{|l|l|}
1.72 \\
\end{tabular} & \begin{tabular}{|l|}
5.48 \\
\end{tabular} & \begin{tabular}{|l|}
0.09 \\
\end{tabular} & 29.96 \\
\hline 727.00 & 165 & 3828 & 119 & \begin{tabular}{|l|}
35.0 \\
\end{tabular} & \begin{tabular}{|l|}
35.6 \\
\end{tabular} & 95 & 21.1 & 157 & 683 & \begin{tabular}{|l|l}
144.0 \\
\end{tabular} & 712 & 8.5 & 2.5 & 6.32 & 0.38 & \begin{tabular}{|l|}
0.96 \\
\end{tabular} & \begin{tabular}{|l|}
7.83 \\
\end{tabular} & 0.23 & \begin{tabular}{|l|l|}
19.17 \\
\end{tabular} \\
\hline 732.80 & 90 & 3859 & 110 & \begin{tabular}{|l|}
47.0 \\
\end{tabular} & 43.0 & 83 & 19.1 & 129 & 697 & \begin{tabular}{|l|}
185.2 \\
\end{tabular} & 1555 & 8.1 & 3.4 & 20.66 & 0.52 & 0.45 & \begin{tabular}{|l|}
4.71 \\
\end{tabular} & \begin{tabular}{|l|}
0.18 \\
\end{tabular} & 16.22 \\
\hline 735.66 & 179 & 3592 & 118 & \begin{tabular}{|l|}
47.1 \\
\end{tabular} & 31.4 & 93 & 20.7 & 163 & 759 & \begin{tabular}{|l|l}
141.0 \\
\end{tabular} & 688 & \begin{tabular}{|l|}
10.1 \\
\end{tabular} & 2.6 & 2.89 & \begin{tabular}{|l|l}
0.34 \\
\end{tabular} & \begin{tabular}{|l|l}
1.10 \\
\end{tabular} & \begin{tabular}{|l|}
8.66 \\
\end{tabular} & \begin{tabular}{|l|}
0.22 \\
\end{tabular} & 24.18 \\
\hline 741.93 & 142 & 3856 & 142 & \begin{tabular}{|l|}
37.8 \\
\end{tabular} & 48.3 & 99 & 20.0 & 151 & 639 & \begin{tabular}{|l|l}
164.6 \\
\end{tabular} & 794 & \begin{tabular}{|l|}
10.4 \\
\end{tabular} & 4.7 & 3.90 & \begin{tabular}{|l|}
0.49 \\
\end{tabular} & \begin{tabular}{|l|}
0.80 \\
\end{tabular} & 7.10 & 0.24 & 13.22 \\
\hline 767.23 & 112 & 5091 & 138 & \begin{tabular}{|l|}
36.3 \\
\end{tabular} & 48.5 & 129 & 32.0 & 315 & 316 & \begin{tabular}{|l|}
274.0 \\
\end{tabular} & 617 & \begin{tabular}{|l|}
16.2 \\
\end{tabular} & 2.2 & \begin{tabular}{|l|}
0.58 \\
\end{tabular} & \begin{tabular}{|l|}
0.38 \\
\end{tabular} & 0.51 & \begin{tabular}{|l|}
3.51 \\
\end{tabular} & 1.00 & 6.53 \\
\hline 855.50 & 67 & 5489 & 127 & \begin{tabular}{|l|}
40.8 \\
\end{tabular} & \begin{tabular}{|l|}
37.0 \\
\end{tabular} & 176 & 32.9 & 211 & 205 & 362.9 & 535 & 15.5 & 2.6 & 18.44 & 0.21 & 0.38 & 2.05 & \begin{tabular}{|l|}
1.03 \\
\end{tabular} & 5.54 \\
\hline 857.55 & 74 & 5602 & 129 & 44.3 & \begin{tabular}{|l|}
40.7 \\
\end{tabular} & 186 & 36.1 & 224 & 228 & 398.9 & 575 & \begin{tabular}{|l|}
16.7 \\
\end{tabular} & 2.7 & 20.27 & 0.22 & $\begin{array}{l}0.40 \\
\end{array}$ & 2.05 & \begin{tabular}{|l|}
0.98 \\
\end{tabular} & 5.60 \\
\hline 858.00 & 73 & 6041 & 123 & \begin{tabular}{|l|}
46.4 \\
\end{tabular} & 36.5 & 187 & 36.9 & 159 & 197 & \begin{tabular}{|l|}
449.4 \\
\end{tabular} & 477 & \begin{tabular}{|l|}
15.6 \\
\end{tabular} & 3.3 & 3.64 & 0.20 & \begin{tabular}{|l|}
0.41 \\
\end{tabular} & \begin{tabular}{|l|}
1.99 \\
\end{tabular} & \begin{tabular}{|l|}
0.81 \\
\end{tabular} & 5.39 \\
\hline 859.83 & 115 & 5248 & 130 & 47.8 & \begin{tabular}{|l|}
39.1 \\
\end{tabular} & 164 & \begin{tabular}{|l|}
30.1 \\
\end{tabular} & 293 & 215 & 259.5 & 750 & 14.9 & 2.0 & 2.99 & 0.24 & 0.29 & 3.82 & \begin{tabular}{|l|}
1.36 \\
\end{tabular} & 5.51 \\
\hline
\end{tabular}

Table 3. Trace element geochemistry (in $\mu \mathrm{g} / \mathrm{g}$ ) of the Xiahuapidianzi Formation mudstone samples.

Palaeoproductivity. The nickel $(\mathrm{Ni})$ and copper $(\mathrm{Cu})$ are dominantly delivered to the sediments in association with OM (organometallic complexes). Moreover, they are often referred to as 'sulfide forming', because there are released through OM decay and can be trapped by pyrite if sulfate-reducing conditions prevail. Consequently, the high contents of $\mathrm{Ni}$ and $\mathrm{Cu}$ in the sediments indicate not only the high organic matter fluid, but also the reducing sedimentary environment. Moreover, even if $\mathrm{OM}$ be remineralized by bacterial activity, $\mathrm{Ni}$ and $\mathrm{Cu}$ could be retained within the sediments, being hosted by pyrite (most frequently). In that way, $\mathrm{Ni}$ and $\mathrm{Cu}$ may speak to the original presence of $\mathrm{OM}$ and consider a representative proxy to $\mathrm{OM}^{34}$. The content of $\mathrm{Ni}$ and $\mathrm{Cu}$ was $26.2-73.0 \mu \mathrm{g} / \mathrm{g}$, mean $=42.5 \mu \mathrm{g} / \mathrm{g}$ and $29.9-48.5 \mu \mathrm{g} / \mathrm{g}$, mean $=37.9 \mu \mathrm{g} / \mathrm{g}$ respectively. The barium (Ba) accumulation rate generally shows a positive correlation with the OM content and primary productivity ${ }^{43}$. The content of Ba was $477-1555 \mu \mathrm{g} / \mathrm{g}$, mean $=704 \mu \mathrm{g} / \mathrm{g}$ (Table 3 ). The TOC content in the sediment can more sensitively reflect the changes of lake organic carbon production and can be used to estimate the ancient productivity of ancient lakes ${ }^{44}$. The TOC of the Xiahuapidianzi Formation varied from 0.48 to $2.35 \%$, with an average of $1.16 \%$.

\section{Discussion}

Volcanic activity during OAE1a. The OAE1a is derived by two mechanisms: (1) the release of massive volcanic $\mathrm{CO}_{2}$ emission $\left({ }^{13} \mathrm{C} \sim-5 \%\right)^{45,46}$ and (2) the dissociation of methane hydrates $\left({ }^{13} \mathrm{C} \sim-60 \%\right)^{7}$. Furthermore, Kuhnt et al. and Yamamoto et al. believe that the negative $\delta^{13} \mathrm{C}$ shift was not short-lived (up to $0.3 \mathrm{Myr}$ ) based on the estimated C3 segment duration ${ }^{47,48}$. Moreover, Wang et al. recorded giant Aptian volcanism in the 
V-Ti

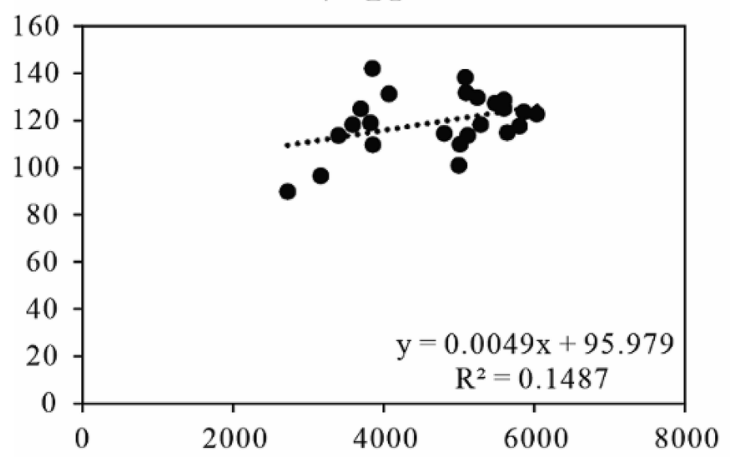

$\mathrm{Ni}-\mathrm{Ti}$

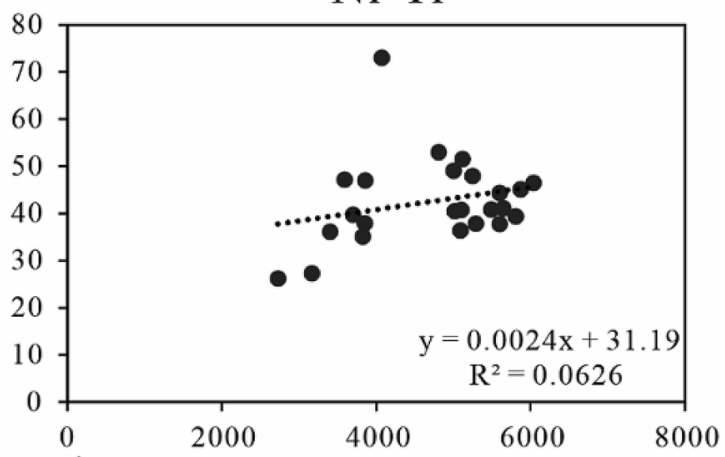

$\mathrm{Ba}-\mathrm{Ti}$

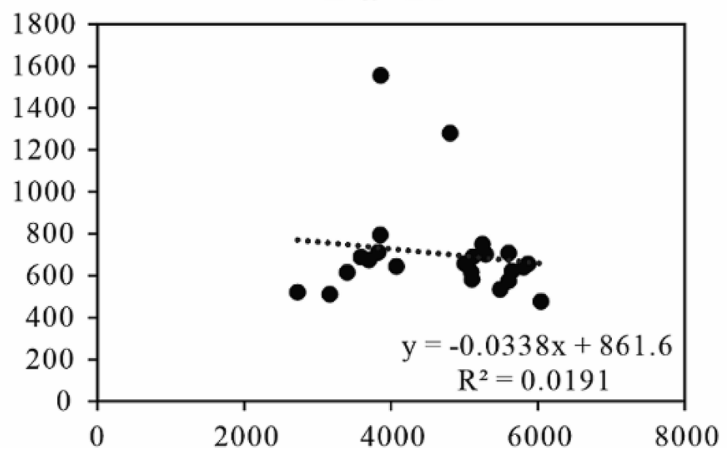

Figure 6. The crossplot of $\mathrm{V}, \mathrm{Ni}, \mathrm{Ba}$, versus $\mathrm{Ti}$ to evaluate the impact of terrigenous debris influence.

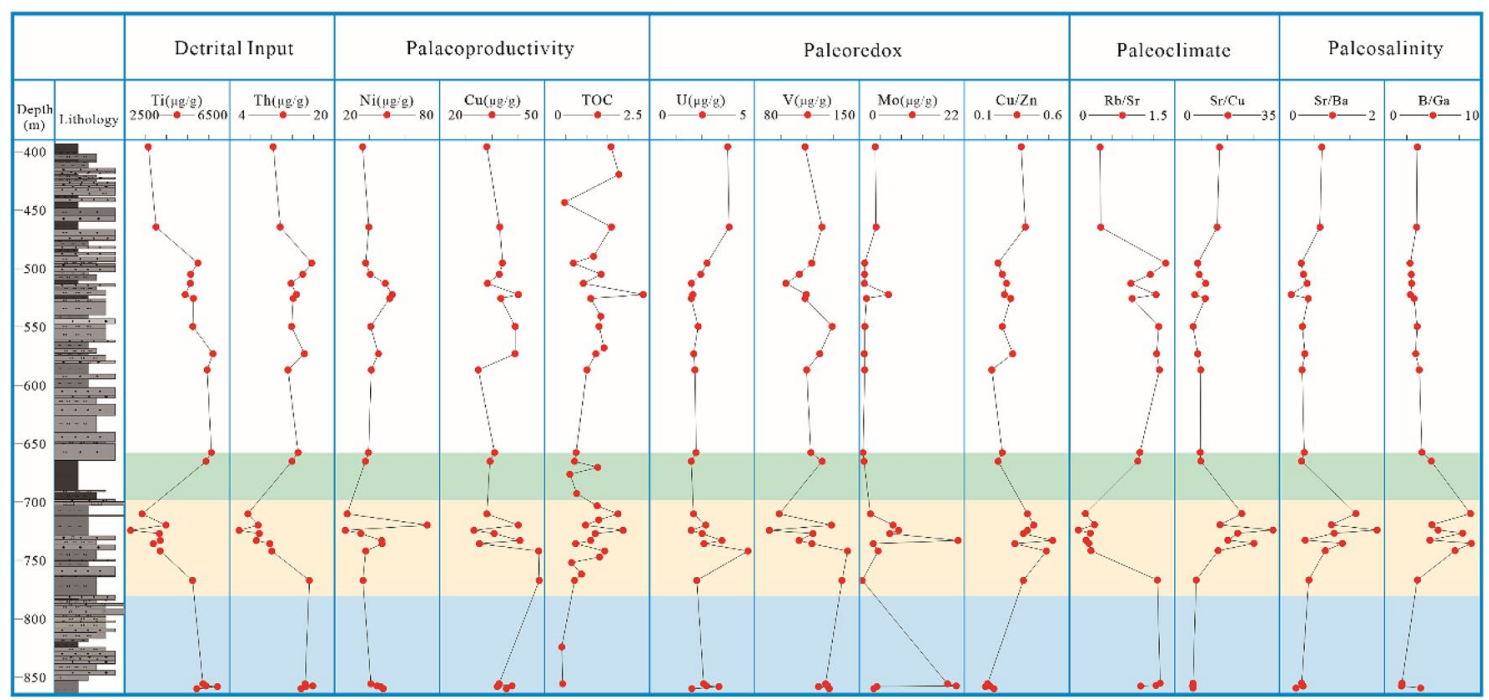

Figure 7. Vertical variations in detrital input indices (Ti, Th), paleoredox indices (U, V, Mo, and $\mathrm{Cu} / \mathrm{Zn})$, paleoproductivity indices $(\mathrm{Ni}, \mathrm{Cu}$ and TOC), paleoclimate indices ( $\mathrm{Sr} / \mathrm{Cu}$ and $\mathrm{Rb} / \mathrm{Sr}$ ), paleosalinity indices ( $\mathrm{Sr} /$ $\mathrm{Ba}$ and $\mathrm{B} / \mathrm{Ga}$ ) for the Xiahuapidianzi Formation in Hongmiaozi basin.

Songliao Basin and Northeast Asia (SB-V) and the Ontong Java plateau (OJP), and it could have contributed to high $\mathrm{CO}_{2}$ and climatic change ${ }^{49}$. Other researchers, such as Erba, Larson and Erba, Tarduno et al., identified a prominent negative $\mathrm{C}$-isotope excursion of the OAE1a by analyzing the volcanic rocks within and around the $\mathrm{SB}-\mathrm{V}^{5,45,50}$. In this study, three volcanic ash layers were found (Fig. 2) within the Xiahuapidianzi Formation (121-118 Ma) as indicated by the intense and frequent volcanic activities during the Xiahuapidianzi Formation deposition. The excursion of pyrite sulfur isotopes $\left(\delta^{34} S_{\mathrm{py}}\right)$ and the sulfur abundance (TS) in the Xiahuapidianzi Formation (Fig. 3 and Table 1) reflect the exogenous $\mathrm{SO}_{4}{ }^{2-}$ input, which has been associated with volcanic activities ${ }^{20}$. 


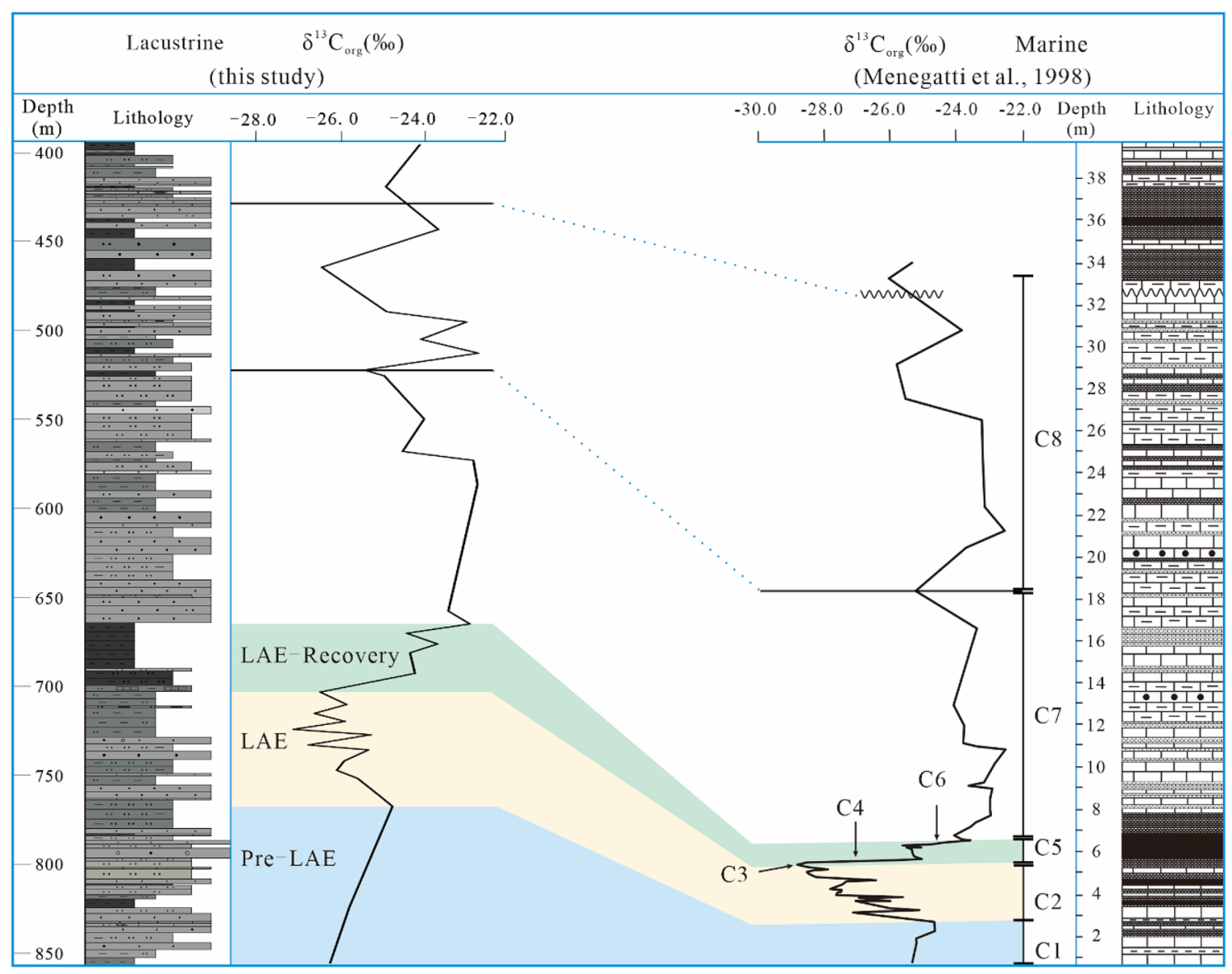

Figure 8. Correlation of the $\delta^{13} \mathrm{C}_{\text {org }}$ curve for the continental Xiahuapidainzi Formation (LAE) with marine strata (OAE) from Italy ${ }^{2}$.

Response of continental lacustrine deposition during OAE1a. Menegatti et al. divided the global ocean isotope change trend during OAE1a into $\mathrm{C} 1-\mathrm{C} 8$ stages $^{2}$ (Fig. 8), which have been widely acknowledged ${ }^{2,47,48,51}$. Figure 8 shows that the $\delta^{13} \mathrm{C}_{\text {org }}$ curve of the lacustrine Xiahuapidianzi Group can be correlated well with the marine curve $(\mathrm{C} 1-\mathrm{C} 8)$ (Fig. 8). We divide the lacustrine anoxic event (LAE) period into the following three phases according to the changes in isotopes (Fig. 3) and trace elements (Fig. 7) to facilitate interpretations of changes in the terrestrial phase under the influence of global anoxia events (LAE) and comparisons with marine changes (OAE) (Fig. 8): Pre-LAE (855.62-767.23 m), LAE (767.23-703.25 m), LAE-recovery $(703.25-665.10 \mathrm{~m})$. Detailed explanations are provided as follows.

Pre-LAE stage. From depths of 860.00 to $767.23 \mathrm{~m}$ (Fig. 8 Pre-LAE), the lithology is argillaceous siltstone, pebbled sandstone, silty mudstone and thin-layer mudstone, thus reflecting a strong hydrodynamic sedimentary environment. The values of $\delta^{13} \mathrm{C}_{\text {org }}$ change from - 26.3 to $-24.8 \%$, showing an increase of $1.5 \%$, which may be related to increased photosynthesis. Studies on modern photosynthetic plants indicated that moderate increases in $\mathrm{pCO}_{2}$ are beneficial to bio-photosynthesis ${ }^{52}$. However, if the $\mathrm{pCO}_{2}$ gradually increases and exceeds a certain $\mathrm{CO}_{2}$ concentration value (e.g., $-20 \%$ to $-35 \%$ ), then photosynthesis will be inhibited or even decease ${ }^{53}$.

Most aquatic organisms use dissolved carbon dioxide as an enzyme substrate. When $\mathrm{CO}_{2}(\mathrm{aq})$ is higher, the selectivity of organisms to ${ }^{12} \mathrm{C}$ is enhanced, and the $\delta^{13} \mathrm{Corg}$ value is negative excursion. When the high productivity caused by algae in the water body, the consumption of $\mathrm{CO}_{2}$ is large and $\mathrm{CO}_{2(\mathrm{aq})}$ is low. When $\mathrm{CO}_{2(\mathrm{aq})}$ is in short supply, organisms will use ${ }^{13} \mathrm{C}$-rich $\mathrm{HCO}_{3}{ }^{-}$(normal lake water temperature $\mathrm{HCO}_{3}^{-}$is $7-10 \%$ o heavier than the $\delta^{13}$ Corg value of dissolved $\mathrm{CO}_{2}$ ) as the enzyme substrate. The $\delta^{13}$ Corg position excursion may prove this ${ }^{54}$.

The $\mathrm{Sr} / \mathrm{Cu}$ and $\mathrm{Rb} / \mathrm{Sr}$ ratios show a warm and humid paleoclimate condition, which is suitable for biophotosynthesis ${ }^{55}$. Therefore, the increase in carbon isotopes corresponds to increased photosynthesis. The TOC and rare element $\mathrm{Ba}$ concentrations are good proxies of paleoproductivity ${ }^{44}$. The TOC varied from 0.43 to 1.43 $\%$ (approximately $1.00 \%$ increase), and Ba varied from 477.4 to $794.3 \mu \mathrm{g} / \mathrm{g}$ (Table 3 ), which indicated that the increased photosynthesis led to an increase in paleoproductivity. The Mo abundance (Table 3) further suggested the increasing organic carbon burial in this abnormal interval ${ }^{56}$.

The $\delta^{34} \mathrm{~S}_{\mathrm{py}}$ value increases from $\sim 11.0$ to $\sim 13.4 \%$ o (about $2.4 \%$ ) and then decreased to $\sim 6.0$. The $\mathrm{TS}_{\text {pyr }}$ values did not show obvious change $(<0.1 \%$ ) (Fig. 3 and Table 1$)$. The $\delta^{34}$ Spy increasing values were mainly caused by $\mathrm{OM}$ rising according to the microbial sulfate reduction (MSR) reaction. With OM growth, ${ }^{32} \mathrm{SO}_{4}{ }^{2-}$ will be 
consumed, which in turn leads to increases in $\delta^{34} \mathrm{~S}_{\mathrm{py}}$, show a reducing environment. However, the decrease of $\delta^{34} \mathrm{~S}_{\mathrm{py}}$ (after the short increase) may suggest an external $\mathrm{SO}_{4}{ }^{2-}$ input, which Berner ascribed to volcanic activities ${ }^{20}$.

The average $\mathrm{Pr} / \mathrm{Ph}$ value is 0.59 at $860.00 \mathrm{~m}$ and 0.25 at $798.00 \mathrm{~m}$, thus indicating a reducing environment, which was probably caused by the promotion of $\mathrm{pCO}_{2}$. The values of $\mathrm{V} /(\mathrm{V}+\mathrm{Ni})<0.84$ and $\mathrm{Cu} / \mathrm{Zn}<0.52$ also indicated a suboxic-dysoxic environment (Table 3). The distribution patterns of $n$-alkanes are considered good indicators of the depositional environment and OM source. Peters et al. demonstrated that $\mathrm{n}$-alkane $\leq \mathrm{nC19}$ is primarily associated with planktonic organisms and/or bacterial communities ${ }^{18}$. Cranwell thought that nC20nC25 are mainly derived from aquatic macrophytes both marine and non-marine ${ }^{57}$ and $>$ nC25 are mainly derived from terrestrial plants ${ }^{18,58,59}$. The $\mathrm{n}$-alkane distribution $(860.00 \mathrm{~m}$ and $798.00 \mathrm{~m}$ in Fig. 5) of the mudstone are $<\mathrm{nC25}$, indicating mixed $\mathrm{OM}$ source inputs from planktonic organisms, bacterial communities and aquatic macrophytes at depths from $860.00 \mathrm{~m}$ to $767.23 \mathrm{~m}$.

The biological pump ${ }^{65}$ can well explain the $\mathrm{CO}_{2}$ conversion to OM by the process $\left[\mathrm{CO}_{2}+\mathrm{H}_{2} \mathrm{O}-\mathrm{CH}_{2} \mathrm{O}\right.$ (POC) $\left.+\mathrm{O}_{2}\right]^{66}$. Large amounts of $\mathrm{CO}_{2}$ were converted to particulate organic carbon (POC) via the biological pump. As $\mathrm{CO}_{2}$ was consumed, the $\mathrm{OM}$ increased in this process. With more organic matter produced in the surface water, it consumes lots of oxygen to degradation before the settlement which will aggravate the formation of suboxic-dysoxic environment.

The initial volcanic activity moderately enhanced $\mathrm{pCO}_{2}$ and important nutrient fluxes (such as biolimiting metals) to the continental lake, which promoted plant photosynthesis. which sustained high biological productivity ${ }^{3,45}$. The productivity increased in the short-term, and the TOC gradually increased. At this stage, the environment was mainly warm and humid sedimentary, and the water bodies were mainly low-oxygen freshwater. Based on these results and analyses, a pattern diagram of the pre-LAE stage (Fig. 8. pre-LAE) was established.

LAE stage. The LAE stage represents the zone at depths between 767.38 and $703.25 \mathrm{~m}$ (Fig. $8 \mathrm{LAE}$ ). The lithology is mainly silty mudstone, calcareous mudstone and argillaceous siltstone interbedded, and the hydrodynamic environment is lower than that of the previous stage. The TIC content of calcareous mudstone increased significantly and was within the range of 3.38-48.0\%. Bischoff and Cummins documented that calcareous mudstone mainly formed in low-lying areas, which experienced seasonal rains and intense evaporation caused by an arid or semiarid climate ${ }^{60}$. In arid climate conditions, the atmospheric precipitation decreases, the water quality becomes salty, the $\mathrm{pH}$ value is higher, the chemical precipitation of calcite is enhanced, and "calcium" is formed. The solubility of calcium carbonate increases with the depth of water. At a certain depth of water, the rate of dissolution of carbonate will be equal to the rate of precipitation. This depth is called carbonate compensation depth (CCD). When the lake bottom is above the compensation depth of carbonate, calcium carbonate is easy to precipitate to form a calcareous layer. Otherwise, the calcium carbonate will dissolve and the calcareous layer cannot be formed. Therefore, the content of calcareous components can reflect changes in lake level up and down or changes in water depth, evolving from a pure mudstone layer to a calcareous layer, and the water depth may have a shallower trend. These may all reflect the change from warm to hot climate.

The $\delta^{13} \mathrm{C}_{\text {org }}$ values range from -24.8 to $-27.2 \%$, indicating an approximately $2.4 \%$ maximum decrease (Fig. 3 and Table 1). The negative excursion of carbon isotope is a typical case of OAE $1 \mathrm{a}^{2,46,61}$. The previous studies on marine isotopes (Fig. 8) indicated an isotopic decline of $\sim 3 \%$ in the C2-C3 stage ${ }^{2}$. There is little doubt that the $\delta^{13} \mathrm{C}_{\text {org }}$ variations in this stage may have resulted from the early Aptian global carbon disturbance. The volcanic activity during this period is probably the main reason for the $\sim 2.4 \%$ carbon isotopic decline in the study area. This assumption is supported by the high atmospheric $\mathrm{pCO}_{2}$ content during the Cretaceous due to the Ontong Java and SB-V volcanic activities ${ }^{6,49,50,56}$, which may contribute to the global greenhouse ${ }^{45,46,50,61}$.

As the proxy of paleoclimate, the ratios of $\mathrm{Sr} / \mathrm{Cu}$ and $\mathrm{Rb} / \mathrm{Sr}$ (Table 3 and Fig. 7) rise up, which reflect a semihumid to hot arid climate. But the ratios of $\mathrm{Sr} / \mathrm{Cu}$ and $\mathrm{Rb} / \mathrm{Sr}$ could be affected by the ion substitution due to similar radius of $\mathrm{Sr}$ and $\mathrm{Ca}^{62}$. Therefore, we combine biomarker and the enrichment factor (EF) for comprehensive analysis and verification the paleoclimate variation.

The n-alkane is C19 at $772.7 \mathrm{~m}$ and C17 at $720 \mathrm{~m}$ (Fig. 5), which are characterized predominantly by planktonic organisms and/or bacterial communities and little with terrestrial high plants. The C29 (m/z=217, depth $=720.00)$ in Fig. 5 show an obvious low, reflect the litter source of terrestrial plants input. The biomarker results reflect that the decrease of terrestrial input, which may cause by the change of climate from warm and humid to hot and arid.

The enrichment factor (EF) could well eliminate the dilute effect of the biogenic carbonate rocks. The enrichment factor of a certain trace element can be expressed as: element factor $(\mathrm{EF})=(\mathrm{C} / \mathrm{X})_{\text {sample }} /(\mathrm{C} / \mathrm{X})_{\text {PAAS }}, \mathrm{C}=$ element, $\mathrm{X}=$ usually are $\mathrm{Al}$ or Th (PAAS = post Archean average Australian shale ${ }^{63}$ ). If the enrichment factor is greater than 1 , it indicates that the element is enriched, otherwise it is depleted. Th only presents four valences, generally not easily soluble in water, and inactive under oxidative conditions, so Th is inactive or very low in the epigenetic zone. The $\mathrm{Sr}_{\mathrm{EF}} \mathrm{Cu}_{\mathrm{EF}}$ and $\mathrm{Ba}_{\mathrm{EF}}$ increase in LAE stage (Fig. 9), show a hot and arid climate change. The ratio of $\mathrm{B} / \mathrm{Ga}$ was originally reported to be related to water salinity ${ }^{30,33,41}$, and the average ratios were 6.69 , which reflect high evaporation and increased salinity in the shrinking water body. The terrigenous detrital proxy, $\mathrm{Zr}, \mathrm{Ti}$, Th (Table 3 and Fig. 7) show a significant decrease at this stage. The increase in salinity and reduce of terrestrial debris also verify the hot and arid climate changes in the depositional environment together with calcareous mudstone petrographic analysis. Zhang, $\mathrm{X}$., and $\mathrm{Li}, \mathrm{S}$ got the same conclusions (hot and arid climate condition) on mudstone and shale samples by the methods of trace elements, quantitative palaeosalinity, carbon and oxygen isotopes in Jiaolai Basin, Shandong Province, Easten China ${ }^{37}$.

The values of $\delta^{34} \mathrm{~S}_{\mathrm{py}}$ range from 6.1 to $16.4 \%$, which indicates an approximately $10.3 \%$ increase. The $\mathrm{TS}_{\mathrm{pyr}}$ values are between 0.20 and $1.35 \%$ (approximately $1.15 \%$ increase, Table 1), the high TS-pyr content and the increased $\delta^{34} S_{\text {py }}$ reflected isotope fractionation caused by the mineralization of OM (MSR). With increasing 


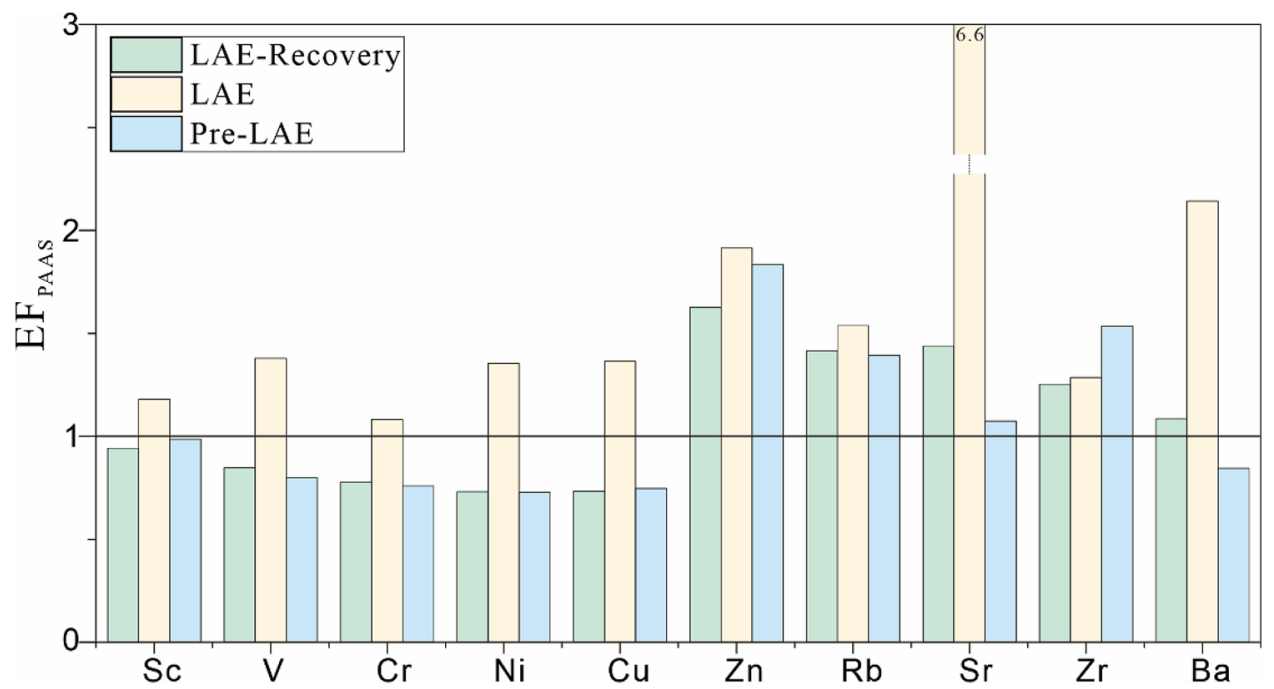

Figure 9. Enrichment factors (EF) results according to post Archean average Australian shale (PASS) standard.

$\delta^{34} \mathrm{SO}_{4}{ }^{2-}$, the $\delta^{34} \mathrm{SO}_{4}{ }^{2-}$ values for pyrite will gradually increase and even exceed the sulfate level of the lake water. This MSR reaction further reflected a reducing environment ${ }^{64}$. The high TS content may imply euxinic environment, support by the enrichment of $\mathrm{U}, \mathrm{V}$ and Mo (Fig. 7), which could infer euxinic deposition environment with $\mathrm{H}_{2} \mathrm{~S}$.

The TOC values increase by $1.04 \%$ (from 0.71 to $1.75 \%$ ). The content of, $\mathrm{Ni}, \mathrm{Cu}$ increasing, indicate a high paleoproductivity which mainly contribute from planktonic organisms and/or bacterial communities differ from Pre-LAE stage. The $\mathrm{Pr} / \mathrm{Ph}$ ratio value was 1.01 at $720.0 \mathrm{~m}$, the $\mathrm{Cu} / \mathrm{Zn}$ ratio was $0.50-0.63$, which further indicated an anoxic condition.

The warm humid to hot arid climate weather due to the high release of $\mathrm{pCO}_{2}$ by intense volcanic activity. The euxinic deposition environment provide a favorable environment for the storage of organic matter. Based on the above evidence and analyses, a pattern diagram of the LAE stage (Fig. 10 LAE) was established.

LAE-recovery stage. The third stage at $703.25 \mathrm{~m}$ and $665.10 \mathrm{~m}$ (Fig. 8 LAE-recovery) mainly included black mud deposits in a lacustrine sedimentary environment. In this stage, the $\delta^{13} \mathrm{C}_{\text {org }}$ of the Xiahuapidianzi Group has undergone a successive two-stage increase with the marine C4-C6 stages (Fig. 8) after the intense decrease of $\delta^{13} \mathrm{C}_{\text {org }}$. The marine C4-C6 stages usually accompany black mudstone deposits (Livello Selli). A $40 \mathrm{~m}$ thick black mudstone deposit was observed in the OAE-recovery stage (Fig. 8), which shows a deeper and more stable sedimentary environment than the OAE stage. The value of $\delta^{13} \mathrm{C}_{\mathrm{org}}$ is within the range of $-26.5 \%$ to $-22.9 \%$, which indicates an increase of $2.6 \%$. The increase in the $\delta^{13} \mathrm{C}_{\text {org }}$ isotope reflected the continuous consumption of $\mathrm{CO}_{2}$ to produce $\mathrm{OM}$ and the termination of OAE 1a under the less active (or ceased) SB-V and OJP volcanism ${ }^{49}$.

The value of $\delta^{34} \mathrm{~S}_{\mathrm{py}}$ is in the range of 3.7 to $9.1 \%$, and the value of $\mathrm{TS}_{\mathrm{pyr}}$ is between $0.42 \%$ and $0.93 \%$ (Table 1). $\delta^{34} \mathrm{~S}_{\mathrm{py}}$ and $\mathrm{TS}_{\mathrm{pyr}}$ still show increases as observed in the LAE stage, although the change is less than that in the LAE stage (Fig. 3) because less OM is available to support the MSR reaction. The decreased TOC value and $\mathrm{Ba}, \mathrm{Ni}, \mathrm{Cu}$ content indicate a decrease in paleoproductivity as the $\mathrm{pCO}_{2}$ value declined. A large amount of $\mathrm{CO}_{2}$ consumption also led to paleoclimate changes from an arid hot to warm humid climate according to the decreased ratios of $\mathrm{Sr} / \mathrm{Cu}$ and $\mathrm{Rb} / \mathrm{Sr}$ (Fig. 7). In the warm humid climate, the detrital input increased and paleosalinity of the lake decreased as indicated by changes in the $\mathrm{Zr}$, Ti, and Th contents and $\mathrm{Sr} / \mathrm{Ba}$ and $\mathrm{B} / \mathrm{Ga}$ ratios (Table 3). The ratios of $\mathrm{Cu} / \mathrm{Zn}, \mathrm{U} / \mathrm{Th}$, and $\mathrm{V} / \mathrm{V}(\mathrm{V}+\mathrm{Ni}$ ) indicate suboxic-anoxic paleoredox conditions.

The $n$-alkanes distribution (C17 to $\mathrm{C} 23$ ) (Fig. 5) reflected the change in OM source from mixed resources $^{18,58,59}$. Based on these evidences and analyses, a pattern diagram of the LAE-recovery stage (Fig. 10 LAE recovery) was established.

\section{Conclusions}

We report a new lacustrine anoxic event (LAE) under the influence of the global OAEla event. The carbon isotope stratigraphic comparison and chronological data show that the Xiahuapidianzi Formation in the Hongmiaozi Basin is a valuable terrestrial research region for studying extreme climate changes (e.g., greenhouse and anoxic) in the Cretaceous.

The comprehensive analysis (e.g., stable carbon sulfur isotope, GC-MS and rare element analyses) of the Xiahuapidianzi Formation indicated that during the deposition period, volcanic activity led to the input of a large amount of greenhouse gases $\left(\mathrm{CO}_{2}\right)$, sulfate, nutrients, etc., which resulted in a significant decrease of carbon and sulfur isotopes. Due to the large amount of greenhouse gases (high $\left.\mathrm{pCO}_{2}\right)$, the climate was significantly warm, even dry and hot climate conditions. Under these conditions, the surface runoff decreased, the lake evaporation and salinity increased, calcareous mudstone was deposited. Moreover, the dry and hot climate and high salinity 


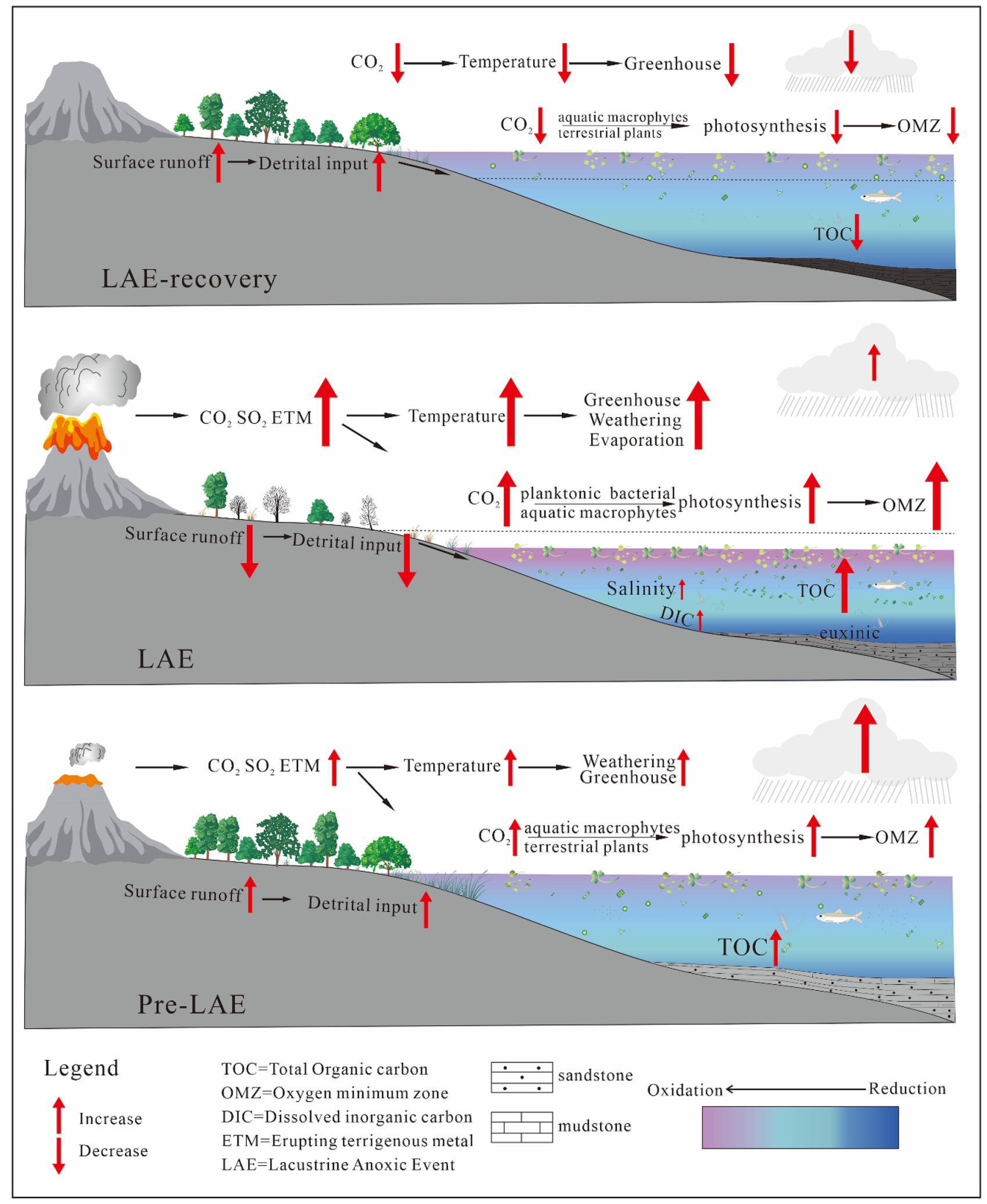

Figure 10. Change model of the different sediment stages (Pre-LAE, LAE, and LAE-recovery) of the continental lake under the influence of the OAEla period (Drawn by Daijun Fan and Yibo Wang). 
may lead to organisms to die and quickly accumulate to form an anoxic to euxinic environment, which are beneficial to the preservation of OM (2.0\% TOC). In the LAE-recovery stage, lake expansion, high productivity and rapid $\mathrm{OM}$ accumulation led to the favorable suboxic-anoxic environment for thick black mudstone storage.

Received: 2 August 2020; Accepted: 2 March 2021

Published online: 31 March 2021

\section{References}

1. Owens, J. D. et al. Sulfur isotopes track the global extent and dynamics of euxinia during Cretaceous Oceanic Anoxic Event 2. Proc. Natl. Acad. Sci. U. S. A. 110(46), 18407-18412 (2013).

2. Menegatti, A.P. et al. High-resolution $\delta^{13} \mathrm{C}$ stratigraphy through the Early Aptian "Livello selli" of the Alpine tethys. Paleoceanogr. Paleoclimatol. 13.5(1998).

3. Leckie, R. M., Bralower, T. J. \& Cashman, R. Oceanic anoxic events and plankton evolution: Biotic response to tectonic forcing during the mid-cretaceous. Paleoceanography 17(3), 13-1-13-29 (2002).

4. Tejada, M. L. G. et al. Ontong java plateau eruption as a trigger for the early Aptian oceanic anoxic event. Geology 37(9), 855-858 (2009).

5. Erba, \& Elisabetta. Nannofossils and superplumes: The early Aptian "nannoconid crisis". Paleoceanography 9(3), 483-501 (1994).

6. Erba, E. et al. Calcareous nannoplankton response to surface-water acidification around Oceanic Anoxic Event 1a. Science 329, 428-432 (2010).

7. Karakitsios, V. et al. First evidence for the early aptian oceanic anoxic event (OAE1a) from the western margin of the pindos ocean (NW Greece). Geobios 51, 187-210 (2018).

8. Naafs, B. D. A. et al. Gradual and sustained carbon dioxide release during Aptian Oceanic Anoxic Event 1a. Nat. Geoence 9(2) (2016).

9. Suarez, M. B. et al. Stable isotope chemostratigraphy in lacustrine strata of the Xiagou formation, Gansu province, NW China. Z. Gastroenterol. 35(4), 285-294 (2015).

10. Zhang, X., Zhang, G. \& Sha, J. Lacustrine sedimentary record of early Aptian carbon cycle perturbation in western Liaoning, China. Cretac. Res. 62(1), 122-129(2016).

11. Kelts, \& K. Environments of deposition of lacustrine petroleum source rocks: An introduction. Geol. Soc. Lond. Spec. Publ. 40(1), 3-26 (1988).

12. Berner, R. A. Geocarbsulf: A combined model for phanerozoic atmospheric $\mathrm{O}_{2}$ and $\mathrm{CO}_{2}$. Geochim. Cosmochim. Acta 70(23), 5653-5664 (2006).

13. Gill, B. C., Lyons, T. W., \& Saltzman, M. R. Parallel. High-resolution carbon and sulfur isotope records of the evolving Paleozoic marine sulfur reservoir. Palaeogeogr. Palaeoclimatol. Palaeoecol. 256(3-4), 156-173 (2007).

14. Wang, J., He, Z., Zhu, D. \& Ding, Q. Geochemical characteristics, depositional environment, and provenance attitude of the Middle Jurassic Yangye Formation lacustrine mudstones in Kashi Sag, south-western Tarim Basin. Geol. J. 55(4), 2976-2994 (2020).

15. Dandan, W. et al. New progress of oil and gas research in the tonghua area, east of the songliao basin. Acta Geol. Sin. (English Edition) 91, 1507-1508 (2017).

16. Xin-Peng, H. et al. Petroleum geologic features and petroleum resources potential in Tonghua Basin. Glob. Geol. 32(2), 337-343(2013).

17. Wang, H. Z. \& Mo, X. X. An outline of the tectonic evolution of china. Episodes 18(1), 6-16 (1995).

18. Peters, K. E., Walters, C. C. \& Moldowan, J. M. The Biomarker Guide-II, Biomarkers and isotopes in Petroleum Systems and Earth History. 475-1155 (Cambridge University Press, 2005).

19. Cao, H. et al. Sulfur isotope constraints on marine transgression in the lacustrine upper cretaceous Songliao basin, northeastern China. Palaeogeogr. Palaeoclimatol. Palaeoecol. 152-163(2016).

20. Berner, R. A. Sedimentary pyrite formation: An update. Geochim. Cosmochim. Acta 48, 605-615 (1984).

21. Kasten, S. \& Jørgensen, B. B. Sulfate reduction in marine sediments [M]. In Marine Geochemistry (eds Schulz, H. D. \& Zabel, M.) 263-275 (Springer, 2000).

22. Tissot, B. P. \& Welte, D. H. Petroleum Formation and Occurrence 2nd edn, 699 (Springer Verlag, 1984).

23. Powell, T. G. \& Mckirdy, D. M. Relationship between ratio of pristane to phytane, crude oil composition and geological environment in Australia. Nature 243(124), 37-39 (1973).

24. Didyk, B. M. et al. Organic geochemical indicators of palaeoenvironmental conditions of sedimentation. Nature 272(5650), 216-222 (1978).

25. Kruge, M.A. et al. Biological markers in Lower Jurassic synrift lacustrine black shales, Hartford basin, Connecticut, U.S.A. Organ. Geochem. 15(3), 281-289 (1990).

26. Sinninghe Damsté, J. S. et al. Evidence for gammacerane as an indicator of water column stratification. Geochim. Cosmochim. Acta 59(9), 1895-1900 (1995).

27. Waples, D. W. \& Machihara, T. Biomarkers for geologists: A practical guide to the application of steranes and triterpanes in petroleum geology. AAPG Methods Exp. 9, 91 (1991).

28. Makeen, Y. M., Abdullah, W. H. \& Hakimi, M. H. Biological markers and organic petrology study of organic matter in the lower cretaceous Abugabra sediments (Muglad Basin, Sudan): Origin, type and palaeoenvironmental conditions. Arab. J. Geosci. 8(1) (2013).

29. Adams, T. D., Haynes, J. R. \& Walker, C. T. Boron in Holocene illites of the Dovey estuary, Wales, and its relationship to palaeosalinity in cyclothems. Sedimentology 4(3), 189-195 (1965).

30. Couch, E. L. Calculation of paleosalinities from boron and clay mineral data. AAPG Bull. 55(10), 1829-1837 (1971).

31. Moradi, A. V., Sari, A. \& Akkaya, P. Geochemistry of the Miocene oil shale (Hançili Formation) in the Çankırı-Çorum Basin, Central Turkey: Implications for paleoclimate conditions, source-area weathering, provenance and tectonic setting. Sed. Geol. 341, 289-303 (2016).

32. Tanaka, K. et al. Rare earth element geochemistry of Lake Baikal sediment: Its implication for geochemical response to climate change during the Last Glacial/Interglacial transition. Quatern. Sci. Rev. 26(9), 1362-1368 (2007).

33. Walker, C. T. Evaluation of boron as a paleosalinity indicator and its application to offshore prospects. AAPG Bull. 52(5), 751-766 (1968).

34. Smrzka, D., et al. The behavior of trace elements in seawater, sedimentary pore water, and their incorporation into carbonate minerals: A review. Facies 65(4) (2019).

35. Beckmann, B. et al. Orbital forcing of cretaceous river discharge in tropical Africa and ocean response. Nature 437(7056), 241-244 (2005).

36. Yang, Y., et al. Diagenesis and sedimentary environment of the lower Xiaganchaigou formation deposited during the Eocene/ Oligocene transition in the Lenghu tectonic belt, Qaidam Basin, China. Environ. Earth Sci. 79.10 (2020).

37. Zhang, X., \& Li, S. A lacustrine record of the early Aptian climate change by oceanic anoxic event (OAE) 1a in the Jiaolai Basin, Eastern China. J. Asian Earth Sci. 104537 (2020). 
38. Jinjun, Xu. et al. High resolution geochemical analysis of organic matter accumulation in the Qingshankou Formation, Upper Cretaceous, Songliao Basin (NE China). Int. J. Coal Geol. 141-142, 23-32 (2015).

39. Fu, X. et al. Elemental geochemistry of the early Jurassic black shales in the QiangTang Basin, eastern Tethys: Constraints for palaeoenvironment conditions. Geol. J. 51(3), 443-454 (2016).

40. Hatch, J. R. \& Leventhal, J. S. Relationship between inferred redox potential of the depositional environment and geochemistry of the Upper Pennsylvanian (Missourian) Stark Shale Member of the Dennis Limestone, Wabaunsee County, Kansas, USA. Chem. Geol. 99(1-3), 65-82 (1992).

41. Nagarajan, Ramasamy, et al. Geochemistry of Neoproterozoic shales of the Rabanpalli Formation, Bhima Basin, northern Karnataka, southern India: implications for provenance and paleoredox conditions. Rev. Mexicana Cienc. Geol. 24(2), 150-160 (2007).

42. Murphy, A.E., et al. Black shale deposition and faunal overturn in the Devonian Appalachian basin: clastic starvation, seasonal water-column mixing, and efficient biolimiting nutrient recycling. Paleoceanography 15(3), 280-291 (2000).

43. Dean, W. E., Gardner, J. V. \& Piper, D. Z. Inorganic geochemical indicators of glacial-interglacial changes in productivity and anoxia on the California continental margin. Geochem. Cosmochim. Acta 61, 4507-4518 (1997).

44. Sarnthein, M., Pflaumann, U., Ross, R., Tiedemann, R. \& Winn, K. Transfer functions to reconstruct ocean palaeoproductivity: A comparison. Geol. Soc. Lond. Spec. Publ. 64(1), 411-427 (1992).

45. Larson, R. L. \& Erba, E. Onset of the mid-Cretaceous greenhouse in the Barremian-Aptian: Igneous events and the biological, sedimentary, and geochemical responses. Paleoceanography 14(6), 663-678 (1999).

46. Bottini, C. et al. Osmium-isotope evidence for volcanism, weathering, and ocean mixing during the early Aptian OAE 1a. Geology 40(7), 583-586 (2012).

47. Kuhnt, W., Holbourn, A. \& Moullade, M. Transient global cooling at the onset of early Aptian oceanic anoxic event (OAE) 1a. Geology 323-326(2011).

48. Yamamoto, K. et al. Early Aptian paleoenvironmental evolution of the Bab Basin at the southern Neo-Tethys margin: Response to global carbon-cycle perturbations across Ocean Anoxic Event 1a. Geochem. Geophys. Geosyst. 14, 1104-1130 (2013).

49. Wang, P., Chen, C. \& Liu, H. Aptian giant explosive volcanic eruptions in the Songliao Basin and northeast Asia: A possible cause for global climate change and OAE-1a. Cretac. Res. 62, 98-108 (2016).

50. Tarduno, J. A. et al. Rapid formation of Ontong java plateau by Aptian mantle plume volcanism. Science 254(5030), 399-403 (1991).

51. Stein, M. et al. Progressive palaeoenvironmental change during the Late Barremian-Early Aptian as prelude to Oceanic Anoxic Event 1a: Evidence from the Gorgo a Cerbara section (Umbria-Marche basin, central Italy). Palaeogeogr. Palaeoclimatol. Palaeoecol. 302, 396-406 (2011).

52. Cure, J. D. \& Acock, B. Crop responses to carbon dioxide doubling: A literature survey. Agric. For. Meteorol. 38(1), 127-145 (1986).

53. Farquhar, S. V. C. D. Some relationships between the biochemistry of photosynthesis and the gas exchange of leaves. Planta 153(4), 376-387 (1981).

54. Mook, W. G., Bommerson, J. C. \& Staverman, W. H. Carbon isotope fractionation between dissolved bicarbonate and gaseous carbon dioxide. Earth Planet. ence Lett. 22(2), 169-176 (1974).

55. Ainsworth, E. A. \& Rogers, A. The response of photosynthesis and stomatal conductance to rising $\left[\mathrm{CO}_{2}\right]$ : Mechanisms and environmental interactions. Plant Cell Environ. 30(3), 258-270 (2007).

56. Zhou, et al. Assessment on redox conditions and organic burial of siliciferous sediments at the Latest Permian Dalong Formation in Shangsi, Sichuan, South China. J. China Univ. Geosci. (2008).

57. Cranwell, P. A. Lipids of aquatic sediments and sedimenting particulates. Prog. Lipid Res. 21(4), 271-308 (1982),

58. Cranwell, P. A. Lipid geochemistry of sediments from Upton Broad, a small productive lake. Org. Geochem. 7(1), 25-37 (1984).

59. Ficken, K. J., Li, B., Swain, D. L. \& Eglinton, G. An n-alkane proxy for the sedimentary input of submerged/floating freshwater aquatic macrophytes. Org. Geochem. 31(7), 745-749 (2000).

60. Bischoff, J. L. \& Cummins, K. Wisconsin glaciation of the Sierra Nevada $(79,000-15,000 \mathrm{yr} \mathrm{B.P.)}$ as recorded by rock flour in sediments of Owens Lake, California. Quatern. Res. 55(1), 14-24 (2001).

61. Taylor, S. R. \& Mclennan, S. M. The Continental Crust: Its Composition and Evolution (Blackwell, 1985).

62. Zhangdong, J. et al. Element distribution in chemical fractions of lake sediments determined by sequential extraction: The case of Lake Daihai (Northern China). J. Lake ence 17.1, 47-53 (2005).

63. Méhay, S. et al. A volcanic $\mathrm{CO}_{2}$ pulse triggered the Cretaceous Oceanic Anoxic Event 1a and a biocalcification crisis. Geology 37, 819-822 (2009).

64. Parrish, J. T. \& Curtis, R. L. Atmospheric circulation, upwelling, and organic-rich rocks in the Mesozoic and Cenozoic eras. Palaeogeogr. Palaeoclimatol. Palaeoecol. 40(1-3), 31-66 (1982).

65. Volk, T. \& Hoffert, M.I. Ocean carbon pumps: analysis of relative strength and efficiencies of in ocean-driven circulation atmospheric $\mathrm{CO}_{2}$ changes. In The Carbon Cycle and Atmospheric $\mathrm{CO}_{2}$ : Natural Variation Archean to Present: AGU Monograph 32 (Sundquist, E.T., Broecker, W.S. Eds.) 99-110. (American Geophysical Union, 1985).

66. Antoine, D. \& Morel, A. Oceanic primary production: 1. Adaptation of a spectral light-photosynthesis model in view of application to satellite chlorophyll observations. Glob. Biogeochem. Cycles 10(1), 43-55 (1996).

\section{Acknowledgements}

We would like to thank Xuanlong Shan for his assistance in revising this paper. Additionally, we would like to thank Dandan Wang, Yinlong Ma, Linkai He, Kai Su and Jianlong Gao for their assistance with sampling. The editors and reviewers carefully reviewed the manuscript and made valuable suggestions for revision. I would like to express my heartfelt thanks! This research is supported by the National Nature Science Foundation of China (No. 41790453).

\section{Author contributions}

D.F. wrote the main manuscript text and prepared all the figures. X.S. and Y.M.M. help manuscript revision and review. W.H., S.S., Y.W., J.Y., G.H., Y.Z. give great help of data analysis and interpretation about this paper. D.F. drawn Figs. 1, 2, 3, 4, 5, 6, 7, 8 and 9. D.F. and Y.W. drawn Fig. 10. All authors reviewed the manuscript.

\section{Competing interests}

The authors declare no competing interests.

\section{Additional information}

Correspondence and requests for materials should be addressed to X.S.

Reprints and permissions information is available at www.nature.com/reprints. 
Publisher's note Springer Nature remains neutral with regard to jurisdictional claims in published maps and institutional affiliations.

(c) (i) Open Access This article is licensed under a Creative Commons Attribution 4.0 International License, which permits use, sharing, adaptation, distribution and reproduction in any medium or format, as long as you give appropriate credit to the original author(s) and the source, provide a link to the Creative Commons licence, and indicate if changes were made. The images or other third party material in this article are included in the article's Creative Commons licence, unless indicated otherwise in a credit line to the material. If material is not included in the article's Creative Commons licence and your intended use is not permitted by statutory regulation or exceeds the permitted use, you will need to obtain permission directly from the copyright holder. To view a copy of this licence, visit http://creativecommons.org/licenses/by/4.0/.

(C) The Author(s) 2021 